\title{
The potential economic feasibility of direct electrochemical nitrogen reduction as a route to ammonia
}

Gal Hochman, ${ }^{* a}$ Alan S. Goldman, ${ }^{* b}$ Frank A. Felder, ${ }^{\mathrm{c}}$ James M. Mayer, ${ }^{\mathrm{d}}$ Alexander J. M. Miller, Patrick L. Holland, ${ }^{\mathrm{d}}$ Leo A. Goldman, ${ }^{\mathrm{a}}$ Patricia Manocha, ${ }^{\mathrm{a}}$ Ze Song, ${ }^{\mathrm{a}}$ Saketh Aleti ${ }^{\mathrm{a}}$

${ }^{a}$ Department of Agriculture, Food \& Resource Economics, Rutgers, The State University of New Jersey, New Brunswick, New Jersey 08901, USA; Email: gal.hochman@rutgers.edu

${ }^{b}$ Department of Chemistry and Chemical Biology, Rutgers, The State University of New Jersey, New Brunswick, New Jersey 08903, USA; Email: alan.goldman@rutgers.edu

${ }^{c}$ Center for Energy, Economic \& Environmental Policy, Edward J. Bloustein School of Planning and Public Policy, Rutgers, The State University of New Jersey, 33 Livingston Avenue, New Brunswick, New Jersey 08901, USA Email: ffelder@rutgers.edu

${ }^{\mathrm{d}}$ Department of Chemistry, Yale University, New Haven, Connecticut 06511, USA. E-mail: patrick.holland@yale.edu, james.mayer@yale.edu

'Department of Chemistry, University of North Carolina at Chapel Hill, Chapel Hill, North Carolina 27599-3290, USA. E-mail: ajmm@email.unc.edu

*Corresponding authors

\begin{abstract}
The Haber-Bosch synthesis produces ammonia from hydrogen and nitrogen gases in a globally important energy-intensive process that uses coal or natural gas as a fuel and as a hydrogen source. Direct electrochemical ammonia synthesis from nitrogen and water using renewable energy sources presents an alternative to the Haber-Bosch process that would be sustainable and environmentally benign. Additionally, the different production structure of direct electrochemical nitrogen reduction technology suggests a supply chain alternative to the ammonia industry, and a method for load-leveling of the electrical grid. This alternative route to ammonia from dinitrogen would not require the same large capital investments as does the Haber-Bosch process, nor would it require access to a fossil fuel supply. We show that under certain scenarios, at feasibly achievable levels of energy efficiency with a future electrocatalyst, direct nitrogen reduction would be economically competitive or advantageous compared with Haber-Bosch-based ammonia production.
\end{abstract}




\section{Introduction}

The world's crop production, which amounted to about $9.5 \times 10^{15}$ calories in 2006 , is projected to increase by $70 \%$ to $1.6 \times 10^{16}$ calories by $2050 .{ }^{1}$ To meet this growing demand, an increased input of nutrients, particularly nitrogen, is needed to support the intensification of agricultural production. ${ }^{2}$ Specifically, ammonia $\left(\mathrm{NH}_{3}\right)$ is produced industrially either for direct use as fertilizer or as the feedstock from which other nitrogen-containing nutrients for plant growth are made. ${ }^{3-4}$ Ammonia is currently synthesized from nitrogen $\left(\mathrm{N}_{2}\right)$ and hydrogen $\left(\mathrm{H}_{2}\right)$ using the Haber-Bosch process (H-B) (eq 1).

$$
\mathrm{N}_{2}+3 \mathrm{H}_{2} \rightleftharpoons 2 \mathrm{NH}_{3}
$$

Haber discovered the underlying catalytic process for H-B around $1908^{5}$ and it currently provides the nitrogen for virtually all synthetic fertilizer. Fertilizer synthesis from the H-B process led to huge increases in crop production in the $20^{\text {th }}$ century ${ }^{5-6}$ and is projected to support half of the world's food production by 2025 , with the share further increasing in subsequent decades. ${ }^{2}$ Current ammonia production is ca. 180 million metric tons $(\mathrm{mt})$ per year $^{7}$ with a growth rate of ca. $4 \%$ projected through $2022 .^{8}$

$\mathrm{H}-\mathrm{B}$ is energy-intensive as currently applied. Natural gas or coal are typically used as fuel and as the source of hydrogen (via steam reforming). The chemical equilibrium of eq 1 lies far to the left side at temperatures required by the current catalytic system; thus, very high pressures (150300 bar $^{9}$ ) are used to drive the reaction to the right. Even at such pressures, however, at chemical equilibrium the conversion to $\mathrm{NH}_{3}$ is only ca. $12-30 \%{ }^{9-11}$ The process is also capital-intensive, requiring large centralized plants to be economical, and a significant input of energy above that of the actual product. It is estimated that about $2 \%$ of the world's fossil fuel is consumed by the process, ${ }^{12}$ with the carbon released as $\mathrm{CO}_{2}$. It is therefore critical to develop a sustainable route to ammonia that is not dependent on fossil fuel. An ideal alternative to H-B would also be a decentralized or distributed method, reducing transportation costs and enabling deployment in locations remote from current ammonia infrastructure. ${ }^{13}$

Ammonia has also received much attention as a medium for storage and transportation of energy. ${ }^{14-22}$ Energy sources in remote locations could be used for the production of ammonia which is relatively easy to ship or transport by pipeline. The ammonia could then be used in fuel cells or combusted for mechanical or electrical energy.

Electrolysis of water followed by H-B (hereinafter E/H-B), and direct electrochemical nitrogen reduction (hereinafter ENR) ${ }^{23-27}$, represent two methods that can use electricity, potentially from renewable energy sources, as the source of energy required for ammonia synthesis. Such processes could significantly reduce or even virtually eliminate the need for fossil fuel and the commensurate emissions of $\mathrm{CO}_{2}$. E/H-B would still require centralized production, because the electrolysisgenerated $\mathrm{H}_{2}$ would be fed into a an H-B plant of the type currently in use. ENR, in contrast, could be more readily decentralized as it obviates the need for H-B. It would thus save the energy and capital costs of running $\mathrm{H}-\mathrm{B}$, and would permit the use of decentralized facilities and distributed 
sources of electricity, thereby reducing the cost of transportation of ammonia to agricultural regions.

The discovery of active electrocatalysts for ENR has proceeded rapidly over the last few years although there are still no reported examples that approach a practical level of efficiency. Reported catalysts have a wide range of different chemical compositions, containing $\mathrm{Bi}, \mathrm{Au}, \mathrm{Mo}, \mathrm{Ag}, \mathrm{Pd}, \mathrm{Fe}$,

and numerous other metals, ${ }^{28-51}$ implying that there is promise for even more reactive and selective catalysts. Very low cathodic overpotentials (as low as $50 \mathrm{mV}^{48}$ ) have been reported. A representative leading catalyst uses molybdenum carbide nanorods to yield up to 95 micrograms $\mathrm{NH}_{3}$ per hour per milligram of catalyst at a cathodic potential of $-0.30 \mathrm{~V}{ }^{52}$ This catalyst system, like others recently reported, achieves a Faradaic efficiency of about $10 \%$ and at $-0.30 \mathrm{~V}$ vs. RHE, a current density of $\sim 25 \mathrm{~mA} / \mathrm{cm}^{2}$. It seems possible that higher current density and selectivity could be achieved at greater driving force using the flow cell strategy recently published by Robert and Berlinguette ${ }^{53}$ for $\mathrm{CO}_{2}$ reduction, enabling ENR to reach industrially relevant current densities above $150 \mathrm{~mA} / \mathrm{cm}^{2}$.

Technoeconomic aspects of ENR have been analyzed from several perspectives. ${ }^{10,22,41,54-60}$ In this article we analyze the conditions that affect the potential economics of ENR, particularly relative to $\mathrm{H}$-B-based ammonia production through either the conventional fossil-fuel based route or via $\mathrm{H}_{2}$ derived from the electrolysis of water $(\mathrm{E} / \mathrm{H}-\mathrm{B})$. In particular, we estimate costs using micro-level dynamic electricity pricing data ${ }^{61}$ to examine how current real-world price fluctuations could affect the costs of ammonia obtained by ENR and by E/H-B. Both ENR and E/H-B are complementary with renewable energy sources such as wind and solar which, due to their intermittency, lead to high variability in pricing due to mismatches between electrical output and demand. By selectively operating when pricing is favorable, such electrochemical processes can take advantage of these supply-demand mismatches. This not only favors their economic potential, but also allows them to act in a "load-leveling" capacity for an electric grid that is significantly based on renewables, thereby favoring the transition to a renewables-based energy system. ${ }^{62-63}$

\section{Ammonia produced via the Haber-Bosch process based on fossil fuel: current practices}

\section{2a. Overview}

The hydrogen feed for H-B can, in principle, be produced via various methods, including natural gas reforming or coal gasification (as well as electrolytic splitting of water in the case of E/H-B) (Fig. 1). Fossil fuel reforming or gasification is intrinsically linked to $\mathrm{CO}_{2}$ production. Natural gas reformation is the most common source of $\mathrm{H}_{2}$, currently used for $72 \%$ of world ammonia production. About $22 \%$ is based on coal gasification, and the remainder mostly based on fuel oil. ${ }^{16}$ Compared with the use of natural gas, other fossil fuels are associated with both significantly greater energy consumption per ton $\mathrm{NH}_{3}$ produced via $\mathrm{H}-\mathrm{B}$ and, additionally, higher emissions of $\mathrm{CO}_{2}$ per unit energy consumed. ${ }^{16,64}$

The nitrogen feed for H-B may be produced as a co-product of coal gasification and natural gas reforming or extracted from air using an air separation unit (ASU). The ASU uses a combination 
of compression, cooling, and expansion to separate the nitrogen from oxygen and other compounds in air, and therefore requires additional energy input. ${ }^{4,65}$

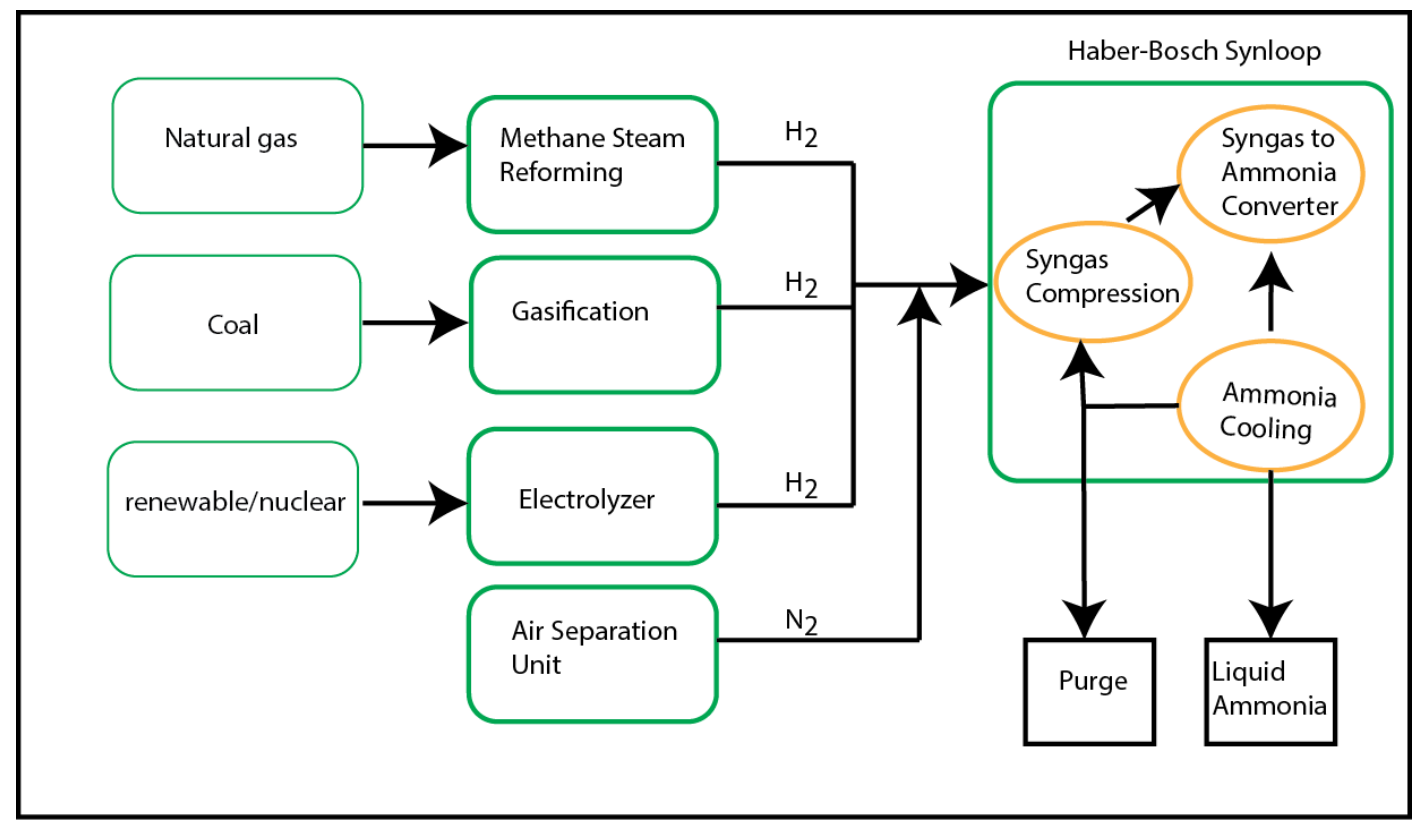

Figure 1: Ammonia synthesis based on Haber-Bosch synthesis using different energy sources

\section{2.b. Energy requirements of H-B based on natural gas}

As noted above, H-B is least energy intensive when based on natural gas among fossil fuels. The net energy input of a typical modern natural-gas-based $\mathrm{H}-\mathrm{B}$ plant, expressed in $\mathrm{MWh} / \mathrm{mt}^{-\mathrm{NH}_{3}}$, is given in Table $1 .^{11}$ The value of $8.87 \mathrm{MWh} / \mathrm{mt}-\mathrm{NH}_{3}$ corresponds to $30.3 \mathrm{MBTU}$ natural gas per mt- $\mathrm{NH}_{3}$. This same value has been independently described as the Best Practice Technology benchmark value for ammonia production. ${ }^{66}$

Table 1: Net energy consumption of a H-B ammonia plant based on natural gas reforming (from reference ${ }^{11}$ )

\begin{tabular}{|l|c|}
\hline Unit Input/Output & $\begin{array}{c}\text { Energy } \\
\left.\text { (MWh/mt- } \mathbf{N H}_{\mathbf{3}}\right)\end{array}$ \\
\hline Feed and Fuel & 9.29 \\
\hline Electricity & 0.05 \\
\hline Steam Export (Output to external hosts) & -0.47 \\
\hline Total & 8.87 \\
\hline
\end{tabular}

\section{2.c. Economics of the Haber-Bosch process}

Following Bartels' (2008) comprehensive data analysis, ${ }^{67}$ the construction cost for a naturalgas-based H-B production facility with a capacity of $2200 \mathrm{mt}-\mathrm{NH}_{3}$ per day is $\$ 740$ million in 2007 dollars or $\$ 889$ million in 2017 dollars ${ }^{68}$ (\$404,000 per $\mathrm{mt}-\mathrm{NH}_{3} /$ day capacity). Of this, $\$ 516$ million is the cost of the H-B synloop and the ASU without the gas turbine $(\$ 235,000$ per mt- 
$\mathrm{NH}_{3}$ /day capacity). The cost of the H-B synloop alone is $\$ 294$ million $\left(\$ 134,000\right.$ per $\mathrm{mt}-\mathrm{NH}_{3} /$ day capacity). Smaller H-B plants (100 to $600 \mathrm{mt}-\mathrm{NH}_{3} /$ day) have recently been constructed at costs corresponding to ca. $\$ 700,000$ per $\mathrm{mt}-\mathrm{NH}_{3} /$ day. ${ }^{69}$

Based on the value of $30.3 \mathrm{MBTU}$ natural gas per $\mathrm{mt}-\mathrm{NH}_{3},{ }^{11,66}$ and using the average Henry Hub natural gas price of \$3.08/MBTU for January, 2017 through December, 2018, (with annual averages of $\$ 2.99$ and $\$ 3.17$ respectively $)^{70}$ the cost for the natural gas required by a plant of the type considered in Table 1 is $\$ 93$ per $\mathrm{mt}-\mathrm{NH}_{3}$ produced.

Using the above construction costs, we estimate the capital cost. We use the assumptions made in the U.S. Department of Energy H2A Distributed Hydrogen Production Model (Version 3), ${ }^{71}$ and considered a capital cost of $5.00 \%$ per year (corresponding to an interest rate of $4.00 \%$ per year repaid over 40 years). At this rate the construction cost of $\$ 404,000$ per $\mathrm{mt}^{-\mathrm{NH}_{3}} /$ day capacity corresponds to $\$ 20,200 /$ year per $\mathrm{mt}-\mathrm{NH}_{3} /$ day capacity, corresponding to $\$ 55 / \mathrm{mt}_{-} \mathrm{NH}_{3}$. To approximate operation and maintenance $(\mathrm{O} \& \mathrm{M})$ costs we use employment values reported for the recently built Yara/BASF ammonia plant (2018 start-up) in Freeport, TX, with a capacity of 2055 mt- $\mathrm{NH}_{3}$ /day with 35 full-time employees. ${ }^{72}$ We use DOE H2A ${ }^{73}$ estimates of salary, administrative costs, and insurance costs, obtaining yearly expenses of $\$ 16.6$ million, or $\$ 22 / \mathrm{mt}_{-} \mathrm{NH}_{3}$.

The estimated capital and O\&M costs, $\$ 55 / \mathrm{mt}-\mathrm{NH}_{3}$ and $\$ 22 / \mathrm{mt}^{-\mathrm{NH}_{3}}$ respectively, combine with the estimated cost of natural gas noted above $\left(\$ 93 / \mathrm{mt}-\mathrm{NH}_{3}\right)$ to contribute $\$ 170 / \mathrm{mt}^{-\mathrm{NH}_{3}}$ to the production cost of ammonia for large plants (Table 2). Smaller plants, ranging from $90 \mathrm{mt}-$ $\mathrm{NH}_{3}$ /day to $550 \mathrm{mt}-\mathrm{NH}_{3}$ /day capacity, incur substantially greater per-ton capital and operating costs, with examples shown in Table $2 .^{69}$

Table 2. Estimated costs of ammonia production $\left(\$ / \mathrm{mt}^{-} \mathrm{NH}_{3}\right)$ via $\mathrm{H}-\mathrm{B}$, by natural-gasbased $\mathrm{H}-\mathrm{B}$ plants of varying capacity (based on a cost of $\$ 3.08 / \mathrm{MBTU}$ natural gas)

\begin{tabular}{|c|c|c|c|}
\hline & \multicolumn{3}{|c|}{ H-B plant size (mt- $\mathrm{NH}_{3} /$ day) } \\
\hline & $\begin{array}{c}\text { Large H-B } \\
\text { (ca. } 2000 \mathrm{mt} / \text { day) }\end{array}$ & $\begin{array}{c}\text { Medium H-B } \\
(545 \mathrm{mt} / \text { day })^{69}\end{array}$ & $\begin{array}{c}\text { Small H-B } \\
(91 \mathrm{mt} / \text { day })^{69}\end{array}$ \\
\hline Natural gas & $\$ 93$ & $\$ 93$ & $\$ 93$ \\
\hline Capital & $\$ 55$ & $\$ 88$ & $\$ 113$ \\
\hline O\&M & $\$ 22$ & $\$ 62$ & $\$ 133$ \\
\hline Total & $\$ 170$ & $\$ 243$ & $\$ 339$ \\
\hline
\end{tabular}

\section{2.d. $\mathrm{CO}_{2}$ emissions from a Haber-Bosch plant}

A minimum of $0.97 \mathrm{mt}-\mathrm{CO}_{2}$ emissions per $\mathrm{mt}-\mathrm{NH}_{3}$ produced is required to provide the necessary hydrogen from the steam reforming of gas (or from direct reaction of gas with $\mathrm{N}_{2}$ ), based only on consideration of the stoichiometry of eq $2\left(3.0 \mathrm{~mol} \mathrm{CH}_{4}\right.$ per mol NH 3$)$. But as eq 2 and methane steam reforming are both endothermic, additional combustion of methane is required, thus increasing the minimum $\mathrm{CO}_{2}$ emissions from a natural-gas-based $\mathrm{H}-\mathrm{B}$ plant. 


$$
3 \mathrm{CH}_{4}(\mathrm{~g})+4 \mathrm{~N}_{2}(\mathrm{~g})+6 \mathrm{H}_{2} \mathrm{O}(\mathrm{g}) \rightleftharpoons 8 \mathrm{NH}_{3}(\mathrm{~g})+3 \mathrm{CO}_{2}(\mathrm{~g})
$$

$\Delta \mathrm{H}^{\circ}{ }_{450}=7.10 \mathrm{kcal} / \mathrm{mol}, \Delta \mathrm{S}^{\circ}{ }_{450}=-106.9 \mathrm{cal} / \mathrm{deg} \cdot \mathrm{mol}, \quad \Delta \mathrm{G}\left(450^{\circ} \mathrm{C}\right)=84.4 \mathrm{kcal} / \mathrm{mol}$

$$
\mathrm{CH}_{4}(\mathrm{~g})+2 \mathrm{O}_{2}(\mathrm{~g}) \rightleftharpoons \mathrm{CO}_{2}(\mathrm{~g})+2 \mathrm{H}_{2} \mathrm{O}(\mathrm{g})
$$

$\Delta \mathrm{H}^{\circ}{ }_{450}=-191.2 \mathrm{kcal} / \mathrm{mol}, \Delta \mathrm{S}^{\circ}{ }_{450}=0.2 \mathrm{cal} / \mathrm{deg} \cdot \mathrm{mol}, \Delta \mathrm{G}\left(450^{\circ} \mathrm{C}\right)=-191.3 \mathrm{kcal} / \mathrm{mol}$

$$
3.5 \mathrm{CH}_{4}(\mathrm{~g})+\mathrm{O}_{2}(\mathrm{~g})+4 \mathrm{~N}_{2}(\mathrm{~g})+5 \mathrm{H}_{2} \mathrm{O}(\mathrm{g}) \rightleftharpoons 8 \mathrm{NH}_{3}(\mathrm{~g})+3.5 \mathrm{CO}_{2}(\mathrm{~g})
$$

$$
\Delta \mathrm{H}^{\circ}{ }_{450}=-65.4 / \mathrm{mol}, \Delta \mathrm{S}^{\circ}{ }_{450}=-68.3 \mathrm{cal} / \mathrm{deg} \cdot \mathrm{mol}, \Delta \mathrm{G}\left(450^{\circ} \mathrm{C}\right)=-11.3 \mathrm{kcal} / \mathrm{mol}
$$

Since eq 2 is only modestly endergonic, while methane combustion (eq 3) is highly exergonic, only a small amount of methane for combustion is thermodynamically required to drive the reaction of eq 2. (With $0.42 \mathrm{~mol} \mathrm{CH}_{4}$ combusted per $3.0 \mathrm{~mol} \mathrm{CH}_{4}$ required for hydrogen, as per eq $\left.2, \Delta \mathrm{G}\left(450^{\circ} \mathrm{C}\right)=0\right)$. Thus eq 4 , in which $0.5 \mathrm{~mol}$ methane are combusted per $3 \mathrm{~mol}$ methane used as a hydrogen source, is highly exothermic and significantly exergonic. We will use this as the approximate theoretical lower limit of $\mathrm{CO}_{2}$ production required for a methane-based $\mathrm{H}-\mathrm{B}$ process, $3.5 \mathrm{~mol} \mathrm{CO}_{2}$ per $8 \mathrm{~mol} \mathrm{NH}_{3}$, or $1.13 \mathrm{~kg}-\mathrm{CO}_{2} / \mathrm{kg}^{-\mathrm{NH}_{3}}$. In practice, various analyses of $\mathrm{H}-\mathrm{B}$ plants conclude that $\mathrm{CO}_{2}$ emissions range from $1.33 \mathrm{mt}-1.69 \mathrm{mt}$ per $\mathrm{mt}-\mathrm{NH}_{3}$ produced. ${ }^{9,11,66,74}$ (Note that these estimates do not include methane leakages, which may significantly increase Greenhouse Gas emissions from H-B.)

The values of energy input, monetary costs, and $\mathrm{CO}_{2}$ emissions quoted and derived in this section are the benchmarks against which the E/H-B and ENR processes will be compared below.

\section{Haber-Bosch using electrochemical $\mathrm{H}_{2}$ production (E/H-B)}

The economics and energy cost of E/H-B can be viewed in terms of the two major components that it comprises: (i) electrochemical $\mathrm{H}_{2}$ production and (ii) the subsequent $\mathrm{H}-\mathrm{B}$ to synthesize $\mathrm{NH}_{3}$ according to eq 1 . While the energy required for the H-B component of the overall process may be obtained from fossil fuel, in this section we examine the limiting case of a potentially carbon-free (in principle) E/H-B system, in which electric power serves as the source of energy to produce $\mathrm{H}_{2}$ as well as the energy needed to drive the H-B synthesis.

The specific energy of $\mathrm{H}_{2}$ is $143 \mathrm{MJ} / \mathrm{kg}$ or $39.7 \mathrm{kWh} / \mathrm{kg}$. The energy efficiency of electrochemical $\mathrm{H}_{2}$ production can be as high as ca. $80 \%$ corresponding to $49.6 \mathrm{kWh}$ required per $\mathrm{kg}-\mathrm{H}_{2}$. For a reference point, at a price of $\$ 0.05 / \mathrm{kWh}(\$ 50 / \mathrm{MWh})$ this corresponds to a cost for electrical power of $\$ 2480 / \mathrm{mt}_{-} \mathrm{H}_{2}$. Assuming $100 \%$ efficiency for the $\mathrm{H}-\mathrm{B}$ synthesis reaction (eq 1 ) $\left(0.178 \mathrm{mt}-\mathrm{H}_{2} / \mathrm{mt}^{-\mathrm{NH}_{3}}\right.$ ) this corresponds to $\$ 441 / \mathrm{mt}^{-\mathrm{NH}_{3}}$ for the $\mathrm{H}_{2}$ feed (Table 3). 
Table 3. Estimated costs of ammonia production $\left(\$ / m t-\mathrm{NH}_{3}\right)$ via $\mathrm{E} / \mathrm{H}-\mathrm{B}$, based on $\mathrm{H} 2 \mathrm{~A}$ model, PEM electrolyzer system with capacity $50 \mathrm{mt}-\mathrm{H}_{2} /$ day, with accompanying $\mathrm{H}-\mathrm{B}$ plants of varying capacity, at a fixed benchmark electric power cost of $\$ 50 / \mathrm{MWh}$

\begin{tabular}{|c|c|c|c|}
\hline & \multicolumn{3}{|c|}{ H-B plant size (mt- $\mathrm{NH}_{3} /$ day) } \\
\hline & $\begin{array}{c}\text { Large H-B } \\
\text { (ca. } 2000 \mathrm{mt} / \text { day) }\end{array}$ & $\begin{array}{l}\text { Medium H-B } \\
\text { (545 mt/day) }\end{array}$ & $\begin{array}{l}\text { Small H-B } \\
\text { (91 mt/day) }\end{array}$ \\
\hline Electricity to produce $\mathrm{H}_{2}$ feed ( $80 \%$ electrical efficiency) & $\$ 441$ & $\$ 441$ & $\$ 441$ \\
\hline Capital cost (electrolyzer only) to produce $\mathrm{H}_{2}$ feed & $\$ 33$ & $\$ 33$ & $\$ 33$ \\
\hline O\&M expenses (electrolyzer only) to produce $\mathrm{H}_{2}$ feed & $\$ 41$ & $\$ 41$ & $\$ 41$ \\
\hline Electricity to run accompanying H-B plant & $\$ 67$ & $\$ 67$ & $\$ 67$ \\
\hline $\begin{array}{l}\text { Capital cost for H-B plant and ASU unit ( } 58 \% \text { of full } \\
\text { gas-based H-B plant) }\end{array}$ & $\$ 32$ & $\$ 51$ & $\$ 66$ \\
\hline $\begin{array}{l}\text { O\&M expenses for H-B plant ( } 58 \% \text { of full gas-based } \\
\text { H-B plant) }\end{array}$ & $\$ 13$ & $\$ 36$ & $\$ 77$ \\
\hline Total & $\$ 627$ & $\$ 669$ & $\$ 725$ \\
\hline
\end{tabular}

Considering the capital and O\&M costs of the electrolysis plant to produce $\mathrm{H}_{2}$, our starting point is the U.S. Department of Energy H2A Distributed Hydrogen Production Model (Version 3), specifically the modeling of a process for production of hydrogen from the electrolysis of water using grid-based electricity. ${ }^{73}$ The system on which we focus is a standalone grid-powered PEM electrolyzer system with hydrogen capacity of $50,000 \mathrm{~kg}(50 \mathrm{mt}) \mathrm{H}_{2} /$ day (corresponding to $282 \mathrm{mt}-$ $\mathrm{NH}_{3}$ /day). Our baseline model is the generic model, which uses process water and grid electricity. Costs are projected for 2040, in 2017 US dollars. The projected total of operating costs (including maintenance and repairs, labor, administrative costs, and insurance) is $\$ 4.2 \mathrm{M}$ per year, while the capital cost of $\$ 67.4 \mathrm{M}$ corresponds to $\$ 3.4 \mathrm{M}$ per year. Assuming that the plant is operating $24 \mathrm{~h}$ per day continuously throughout the year ("24/7"), these values correspond to capital costs of $\$ 186 / \mathrm{mt}^{-} \mathrm{H}_{2}$ and operating costs of $\$ 230 / \mathrm{mt}-\mathrm{H}_{2}$, or $\$ 33 / \mathrm{mt}-\mathrm{NH}_{3}$ and $\$ 41 / \mathrm{mt}_{-}-\mathrm{NH}_{3}$ respectively, required to produce the necessary $\mathrm{H}_{2}$ synthesis feed.

In addition to the energy required to produce the $\mathrm{H}_{2}$ feed, the energy requirements to operate the associated H-B plant may be estimated, at least as a crude approximation, based on the total energy required of a highly integrated natural-gas-based $\mathrm{H}-\mathrm{B}$ production facility. The most favorable estimate of such $\mathrm{CO}_{2}$ emissions is $1.33 \mathrm{mt} / \mathrm{mt}^{-N_{3}} 3{ }_{3}{ }^{74}$ implying an efficiency of $85 \%$ compared with the theoretical value of $1.13 \mathrm{mt}-\mathrm{CO}_{2} / \mathrm{mt}^{-\mathrm{NH}_{3}}$. This implies that $15 \%$ of the full energy requirement of an integrated gas-based plant may be taken as a minimum for plant operation. Therefore, to a first approximation we use $4.55 \mathrm{MBTU}$ ( $15 \%$ x $30.3 \mathrm{MBTU})$ or 1.33

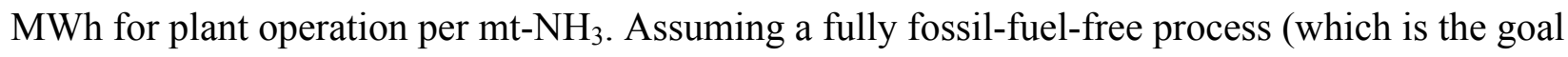
of electrochemical systems for $\mathrm{NH}_{3}$ production) and obtaining this energy as electrical power, using the benchmark electric power price of $\$ 50 / \mathrm{MWh}$ this corresponds to $\$ 67 / \mathrm{mt}-\mathrm{NH}_{3}$ for the energy required to power the H-B component of an E/H-B system. 
As noted in Section 2.c., the total capital for a 2200-mt/day ammonia plant, including H-B synloop and ASU, but without the gas turbine, is about $\$ 516$ million or $58 \%$ of the cost of a full $\mathrm{H}$ B plant of the same capacity. This would contribute a capital cost of $\$ 25.8$ million/year, corresponding to $\$ 32 / \mathrm{mt}^{-\mathrm{NH}_{3}}$ assuming $24 / 7$ operation. We will crudely approximate that O\&M costs for this natural-gas-free $\left(\mathrm{H}_{2}\right.$-based $) \mathrm{H}$-B plant will be of the same proportion to capital cost, i.e. 58\% that of a full natural-gas-based $\mathrm{H}-\mathrm{B}$ plant. Using the values estimated for the aforementioned Yara/BASF plant yields an O\&M cost of $\$ 13 / \mathrm{mt}_{-} \mathrm{NH}_{3}$ for this $\mathrm{H}_{2}$-based H-B plant. For smaller $\mathrm{H}_{2}$-based $\mathrm{H}$-B plants, which are of a size more commensurate with the $50-\mathrm{mt}_{-} \mathrm{H}_{2} /$ day capacity of the electrolyzer for $\mathrm{H}_{2}$ production under consideration, we will also estimate the capital cost and O\&M costs to be of the same proportion (58\%) to that of a natural-gas-based H-B plant of the same lower capacity. Specifically, we use the costs obtained for the same representative 545mt- $\mathrm{NH}_{3}$ /day and 91-mt- $\mathrm{NH}_{3} /$ day plants considered in Section 2.c.

The total costs of ammonia production from E/H-B plants that use electrochemically produced $\mathrm{H}_{2}$ for feed and fuel can now be estimated. The values obtained, based on the benchmark electric power price of $\$ 50 / \mathrm{MWh}$ and other conditions assumed above, are summarized in Table 3 . At the largest economy of scale, the total cost is estimated as $\$ 627 / \mathrm{mt}_{-} \mathrm{NH}_{3}$, with higher costs incurred with smaller-scale accompanying H-B plants.

\section{Direct Electrochemical Nitrogen Reduction (ENR)}

\section{4.a. Overview}

The ENR process comprises oxidation of water at the anode to yield $\mathrm{O}_{2}$ and $\mathrm{H}^{+}$(eq 5) and reduction of $\mathrm{N}_{2}$ at the cathode and protonation to yield ammonia (eq 6) (Fig. 2).

$$
\begin{aligned}
& \text { At the anode: } \quad 3 \mathrm{H}_{2} \mathrm{O} \rightarrow \frac{3}{2} \mathrm{O}_{2}+6 \mathrm{e}^{-}+6 \mathrm{H}^{+} \\
& \text {At the cathode: } \quad 6 \mathrm{e}^{-}+6 \mathrm{H}^{+}+\mathrm{N}_{2} \rightarrow 2 \mathrm{NH}_{3}
\end{aligned}
$$




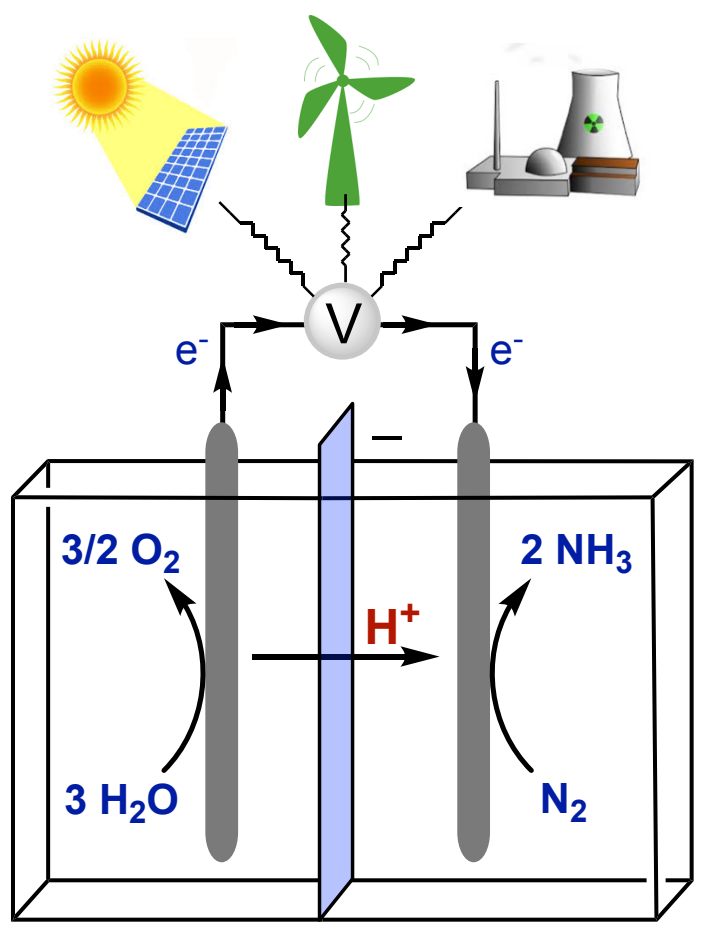

Figure 2. Schematic of sustainable electrochemical nitrogen reduction

The electrochemical potentials at standard state (1 M solutes, 1 atm gases, $298 \mathrm{~K}$ ) for these half-reactions, and the potential for the overall reaction, are given in equations 7-9. ${ }^{75-76}$ All potentials are presented versus the standard hydrogen electrode, SHE.

$$
\begin{aligned}
& \mathrm{N}_{2}+6 e^{-}+6 \mathrm{H}^{+} \rightarrow 2 \mathrm{NH}_{3}(\mathrm{aq}) ; E^{0}=+0.092 \mathrm{~V} \\
& 3 \mathrm{H}_{2} \mathrm{O} \rightarrow 1.5 \mathrm{O}_{2}+6 e^{-}+6 \mathrm{H}^{+} ;-\left(E^{0}=+1.229 \mathrm{~V}\right) \\
& \mathrm{N}_{2}+3 \mathrm{H}_{2} \mathrm{O} \rightarrow 2 \mathrm{NH}_{3}+1.5 \mathrm{O}_{2} ; E^{0}=-1.137 \mathrm{~V}
\end{aligned}
$$

From equation 9 and the Nernst equation we can obtain the baseline thermodynamic freeenergy requirements for ENR, which corresponds to a minimum energy input of $5.37 \mathrm{MWh} / \mathrm{mt}-$ $\mathrm{NH}_{3}$. (Note eqs 7-9 are at standard state conditions of $1 \mathrm{M} \mathrm{H}^{+}$, where $\mathrm{NH}_{3}$ would be protonated as $\mathrm{NH}_{4}{ }^{+}$, leading to an anodic shift in $E^{\mathrm{o}}$ for eq 7 by $+0.28 \mathrm{~V}$ vs SHE. The more general case of $\mathrm{NH}_{3}$ production is considered here.)

The efficiency of an electrochemical synthesis such as ENR is determined by the overpotential required to generate product (i.e., the operating voltage that is beyond the thermodynamic potential) and the Faradaic efficiency (the fraction of the current that leads to the desired product). The electrochemical half-reactions of eq 7 and 8 will each have a distinct overpotential and Faradaic efficiency, which can be combined to estimate the overall overpotential and Faradaic efficiency of the full electrochemical cell. The overpotential derives from two factors, the need for higher voltage to drive the catalytic chemistry at each electrode and electrical resistive losses in the electrolyzer. On the basis of overpotential literature values for independent studies of the half- 
reactions of eq 7 and eq 8 , we consider $0.6 \mathrm{~V}$ to be a feasible aspirational full cell overpotential for eq $9,^{77}$ and $1.2 \mathrm{~V}$ to be an approximate likely upper limit (considering that if greater cathodic overpotentials are used there is likely to be substantial undesired reduction of $\mathrm{H}^{+}$). We combine the full cell overpotential and Faradaic efficiency to define a total energy efficiency according to eq 10, where FE denotes Faradaic efficiency, TE denotes thermodynamic voltage requirement which equals $1.137 \mathrm{~V}$, and TV denotes total voltage (TE plus full-cell overpotential). Table 4 gives $\mathrm{EE}$ as defined in eq 10 at several levels of $\mathrm{FE}$ and at $0.6 \mathrm{~V}$ and $1.2 \mathrm{~V}$ overpotential (as well as a limiting, purely theoretical, case of $0.0 \mathrm{~V}$ ), and the resulting cost of electrical energy per $\mathrm{mt}^{-\mathrm{NH}_{3}}$ produced, assuming a cost of $\$ 50 / \mathrm{MWh}$. For benchmarking purposes, we will focus on the aspirational values of $95 \%$ Faradaic efficiency and $0.60 \mathrm{~V}$ overpotential, at which EE is $62.2 \%$. With a hypothetical electricity cost of $\$ 50 / \mathrm{MWh}$ this yields an energy cost of $\$ 432$ per $\mathrm{mt}_{-} \mathrm{NH}_{3}$ produced.

$$
E E=F E \times \frac{T E}{T V}
$$

Table 4. Energy input required for $\mathrm{NH}_{3}$ production via ENR at overpotentials of $0.6 \mathrm{~V}$ and $1.2 \mathrm{~V}$ and various Faradaic efficiencies, and corresponding electrical energy costs per $\mathrm{mt}-\mathrm{NH}_{3}$ produced, at a fixed electricity price of $\$ 50 / \mathrm{MWh}$

\begin{tabular}{|c|c|c|c|c|}
\hline $\begin{array}{c}\text { Overpotential } \\
\text { (V) }\end{array}$ & FE & EE & $\begin{array}{c}\text { Energy input } \\
\left(\mathbf{M W h} / \mathbf{m t}-\mathbf{N H}_{3}\right)\end{array}$ & $\begin{array}{c}\text { Electricity cost } \\
\left(\mathbf{\$} / \mathbf{m t}_{\mathbf{N}} \mathbf{)}\right.\end{array}$ \\
\hline $\mathbf{0}$ & $100 \%$ & $100.0 \%$ & 5.37 & $\$ 268.5$ \\
\hline $\mathbf{0 . 6}$ & $100 \%$ & $65.5 \%$ & 8.20 & $\$ 410.2$ \\
\hline $\mathbf{1 . 2}$ & $100 \%$ & $48.7 \%$ & 11.04 & $\$ 551.9$ \\
\hline $\mathbf{0 . 6}$ & $\mathbf{9 5 \%}$ & $\mathbf{6 2 . 2 \%}$ & $\mathbf{8 . 6 4}$ & $\$ 431.8$ \\
\hline $\mathbf{1 . 2}$ & $95 \%$ & $46.2 \%$ & 11.62 & $\$ 580.9$ \\
\hline $\mathbf{0 . 6}$ & $80 \%$ & $52.4 \%$ & 10.25 & $\$ 512.7$ \\
\hline $\mathbf{1 . 2}$ & $80 \%$ & $38.9 \%$ & 13.80 & $\$ 689.8$ \\
\hline $\mathbf{0 . 6}$ & $60 \%$ & $39.3 \%$ & 13.67 & $\$ 683.6$ \\
\hline $\mathbf{1 . 2}$ & $60 \%$ & $29.2 \%$ & 18.40 & $\$ 919.8$ \\
\hline
\end{tabular}

\section{4.b. Economics of ENR at a fixed price of electrical power}

We base our estimated projections of capital and operation costs for a ENR system on the same values as used for electrochemical $\mathrm{H}_{2}$ production, using the same costs per unit of current, and assuming a fixed-proportion relation between cost structure and electric current. Thus, an ammonia plant would produce $5.63 \mathrm{~g} \mathrm{NH}_{3}(0.3333 \mathrm{~mol} \mathrm{x} 17.03 \mathrm{~g} / \mathrm{mol})$ as compared with $1.0 \mathrm{~g} \mathrm{H}_{2}(0.5 \mathrm{~mol} \mathrm{x}$ $2.016 \mathrm{~g} / \mathrm{mol}$ ) per unit current from a hydrogen plant. The H2A Project capacity of $50 \mathrm{mt}-\mathrm{H}_{2} /$ day thus implies $282 \mathrm{mt}-\mathrm{NH}_{3}$ /day produced with comparable investments and costs. Additionally, an air separation unit would be required for the ENR plant. Based on data from Andersson, ${ }^{54}$ we estimate the cost of the ASU unit for such a plant to be $\$ 4.6 \mathrm{M}$, which we add to the total capital 
cost of $\$ 67.4 \mathrm{M}$ for the corresponding PEM electrolyzer system with hydrogen capacity of $50 \mathrm{mt}-$ $\mathrm{H}_{2} /$ day, for a total of $\$ 72.0 \mathrm{M}$. O\&M expenses, as given above for the E/H-B system are $\$ 4.2 \mathrm{M}$ year. This baseline scenario suggests a cost of $\$ 508 / \mathrm{mt}_{-} \mathrm{NH}_{3}$, assuming electricity priced at $\$ 50 / \mathrm{MWh}$ and the same parameters as applied to estimate costs of ammonia production via $\mathrm{H}-\mathrm{B}$ and $\mathrm{E} / \mathrm{H}-\mathrm{B}$ (Table 5).

Table 5. Estimated costs of ammonia production $\left(\$ / \mathrm{mt}-\mathrm{NH}_{3}\right)$ via ENR, at $62.2 \% \mathrm{EE}$ and a fixed benchmark electric power cost of $\$ 50 / \mathrm{MWh}$

\begin{tabular}{|l|c|}
\hline & Cost $\mathbf{( \$ / \mathrm { mt } _ { - } \mathrm { NH } _ { \mathbf { 3 } } )}$ \\
\hline Electricity to produce $\mathbf{N}_{\mathbf{2}}$ feed $\left.\mathbf{( 6 2 \%} \mathrm{EE}\right)$ & $\$ 432$ \\
\hline Capital & $\$ 35$ \\
\hline O\&M & $\$ 41$ \\
\hline \multicolumn{1}{|c|}{ Total } & $\$ 508$ \\
\hline
\end{tabular}

\section{4.c. Effects of fluctuations in electricity prices}

We have identified above the parameters determining the cost of ENR at a given price for electric power. But electricity prices of course vary widely depending upon numerous factors, and can fluctuate significantly over time, within a day, over a week, and across seasons. We next investigate the economic viability of a simulated ENR ammonia plant while allowing production of $\mathrm{NH}_{3}$ to vary depending on fluctuation in electricity prices, using pricing obtained from the Electric Reliability Council of Texas (ERCOT) in the U.S. ${ }^{78}$ ERCOT manages the flow of electricity in most of Texas and performs financial settlement for the competitive wholesale bulkpower market and administers retail switching. Quarter-hourly wholesale ERCOT real-time market price data was used for the period January - December 2017. Variability in pricing is significant. For example, for the ERCOT West Hub, the average price was $\$ 22.31 / \mathrm{MWh}$ while the price at the 99-percentile level was $\$ 93.5 / \mathrm{MWh}$ and at the 1-percentile level was negative, at $-\$ 2.62 / \mathrm{MWh}$.

For purposes of this analysis we assume that the difference between industrial and wholesale ERCOT prices is fixed and therefore the difference between the industrial and wholesale prices equals the difference between the average annual industrial price and the average wholesale price. We use the U.S. EIA annual industrial electricity price data for Texas ${ }^{79}$ together with ERCOT wholesale prices $^{78}$ (i.e., $p_{\text {wholesale }}^{E R C O T}$ ), to calculate this difference.

$$
\Delta=\text { annual } p_{\text {Industrial }}-\text { annual } p_{\text {wholesale }}
$$

We assume that the price obtained by the ENR ammonia plant would be less than or equal to the standard industrial price, $p_{\text {Industrial }}^{\text {Calculated }}$ (eq).

$$
p_{\text {Industrial }}^{\text {Calculated }}=\Delta+p_{\text {wholesale }}^{\text {ERCOT }}
$$

The average industrial electricity price paid in Texas in 2017 was $\$ 53.5 / \mathrm{MWh}$ while the average wholesale electricity price the same year, for all hubs/loading zones in the ERCOT 
system, was $\$ 25.4 / \mathrm{MWh}$. Thus, the average value of $\Delta$ is approximately $\$ 30 / \mathrm{MWh}$. We will consider this value, but we will also consider the likelihood that an ammonia plant, due to large scale, and especially by choosing a favorable location, might obtain a significantly more favorable price for delivery of electric power.

Based on quarter-hourly rates and $\Delta$ we calculate the annual cost of ammonia production by an ENR plant, assuming that production is discontinued when electricity costs rise above various values ("cut-offs"). These values correspond to various pricing percentiles; selected percentiles are shown in Table 6 . The total cost per $\mathrm{mt}_{-} \mathrm{NH}_{3}$, including electricity, capital, and O\&M, is calculated according to eq 13.

total cost $/ \mathrm{mt}^{-\mathrm{NH}_{3}}=5.37 \mathrm{MWh}\left(\mathrm{PE}_{\text {cut }}+\Delta\right) / \mathrm{EE}+\mathrm{FC} / \mathrm{OT}$

- $\quad \mathrm{PE}_{\text {cut }}$ : average price paid for electrical energy (per MWh) for operation times (i.e. when price per $\mathrm{MWh}$ is below the given cut-off)

- FC: Fixed annual costs (capital cost plus O\&M) divided by $24 / 7$ capacity in mt- $\mathrm{NH}_{3} /$ year

- OT: Operating time as a fraction of full time (equal to the percentile value corresponding to the cutoff price)

Lower price cut-offs will of course correspond to lower electricity costs per unit ammonia production, but fixed costs (capital and operating) will then be greater when calculated on a perton basis. Here we consider the lowest possible total cost per ton at which ammonia can be produced (including capital and O\&M costs), at various assumed levels of EE, $\Delta$, and fixed costs. This would allow a potential investor to determine if a plant could be profitable in the scenario of a given distribution of electrical pricing and a given ammonia price. Once the plant is operational, however, under this very simple model scenario, the plant would in principle produce ammonia whenever the cost of electricity (the marginal production cost) is less than the price for which the ammonia could be sold, allowing it to further maximize profit accordingly.

Assuming the various levels of energy efficiency given in Table 4, and various values of $\Delta$, we calculate the annual per-ton cost of ammonia production at various electricity price cut-offs, each corresponding to a certain percentage (OT) of continuous operation. Values obtained using pricing from the ERCOT West Hub, which has the lowest average power cost of ERCOT hubs or loading zones, are shown in Table 6 . The minimum per-mt- $\mathrm{NH}_{3}$ production cost for each set of conditions is highlighted, and the minima for the aspirational 62.2\% energy efficiency are shown in red. 
Table 6. Total cost (USD, energy plus fixed costs) per $\mathrm{mt}^{-\mathrm{NH}_{3}}$ produced via ENR as a function of EE, electricity cost, capital and operating expenses, with varying electricity pricing cut-offs for operation using 2017 ERCOT real-time market prices (ERCOT West Hub).

\begin{tabular}{|c|c|c|c|c|c|c|c|c|c|c|c|c|}
\hline & & & 1 & 2 & 3 & 4 & 5 & 6 & 7 & 8 & 9 & 10 \\
\hline \multicolumn{3}{|c|}{ Energy Efficiency } & $100 \%$ & $100 \%$ & $65 \%$ & $62 \%$ & $62 \%$ & $62 \%$ & $39 \%$ & $29 \%$ & $62 \%$ & $62 \%$ \\
\hline \multicolumn{3}{|r|}{$\Delta(\$ / M W h)^{a}$} & 20 & 30 & 25 & 10 & 20 & 30 & 25 & 25 & 25 & 25 \\
\hline $\begin{array}{l}\text { energy cost } \\
\text { cut-off } \\
(\$ / M W h)^{c}\end{array}$ & $\begin{array}{c}\% \text { time } \\
\text { operating }^{d}\end{array}$ & $\begin{array}{c}\text { average } \\
\text { energy cost } \\
(\$ / \mathrm{MWh})^{\mathrm{e}}\end{array}$ & \multicolumn{10}{|c|}{ Total cost (electricity plus fixed) $\left(\$ / M T-\mathrm{NH}_{3}\right)$} \\
\hline 43.7 & 97 & 19.44 & 290 & 344 & 443 & 332 & 419 & 505 & 691 & 896 & 540 & 423 \\
\hline 33.6 & 94 & 18.86 & 289 & 343 & 440 & 330 & 416 & 503 & 686 & 887 & 540 & 419 \\
\hline 30.3 & 90 & 18.29 & 290 & 343 & 439 & 328 & 415 & 501 & 681 & 881 & 542 & 416 \\
\hline 27.5 & 85 & 17.67 & 291 & 345 & 439 & 328 & 414 & 501 & 678 & 874 & 547 & 413 \\
\hline 10.7 & 10 & 1.23 & 871 & 925 & 972 & 854 & 940 & 1027 & 1119 & 1240 & 1741 & 605 \\
\hline-2.6 & 1 & -7.69 & 7636 & 7690 & 7712 & 7590 & 7676 & 7763 & 7809 & 7888 & 15289 & 3934 \\
\hline \multicolumn{3}{|c|}{ per ton cost energy only $(24 / 7)^{f}$} & 120 & 120 & 183 & 193 & 193 & 226 & 308 & 410 & 193 & 193 \\
\hline \multicolumn{3}{|c|}{ per ton cost energy $+\Delta(24 / 7)^{g}$} & 227 & 281 & 388 & 279 & 365 & 530 & 653 & 870 & 409 & 409 \\
\hline \multicolumn{3}{|c|}{ per ton fixed costs $(24 / 7)^{\mathrm{h}}$} & 75.7 & 75.7 & 75.7 & 75.7 & 75.7 & 75.7 & 75.7 & 75.7 & 151.4 & 37.85 \\
\hline \multicolumn{3}{|c|}{ per ton total costs $(24 / 7)$} & 303 & 357 & 464 & 355 & 441 & 605 & 728 & 946 & 560 & 446 \\
\hline
\end{tabular}

a) $\Delta$ : difference between wholesale electricity price and price paid

b) Fixed costs (capital and operating expenses) per mt assuming full-time operation at capacity

c) Greatest wholesale electricity price at percent operating time indicated (i.e. pricing at percentile indicated)

d) Percent time operating, assuming full operation at indicated pricing level or lower

e) Average cost of energy during time operating

f) Energy cost (not including $\Delta$ ) per mt assuming full-time operation at capacity

g) Energy cost (including $\Delta$ ) per mt assuming full-time operation at capacity

Considering first the purely theoretical case of a $100 \%$ energy-efficient process, and $\Delta=$ $\$ 20 / \mathrm{MWh}$, the production cost of ammonia with this scenario is $\$ 303 / \mathrm{mt}^{-\mathrm{NH}_{3}}$ (Table 6 , column 1) if the plant operates without interruption throughout the year ("24/7"). By discontinuing operation when prices are above $\$ 43.7 / \mathrm{MWh}$ (corresponding to $97 \%$ operation) a slightly lower production cost of $\$ 290 / \mathrm{mt}_{-} \mathrm{NH}_{3}$ can be achieved, with a very slightly lower minimum $\left(\$ 289 / \mathrm{mt}-\mathrm{NH}_{3}\right)$ achieved by operating about $94 \%$ of the time. If it is assumed that $\Delta=\$ 30 / \mathrm{MWh}$ (column 2 ) instead of $\$ 20 / \mathrm{MWh}$, the cost will be an additional $\$ 53.7 / \mathrm{mt}^{-\mathrm{NH}_{3}}$ at $100 \%$ efficiency (at which, production requires $5.37 \mathrm{MWh} / \mathrm{mt}^{-N_{3}}$ ). Note that the value of $\Delta$ does not affect the percent of time operating at which minimum per-tonne cost is achieved.

Assuming a feasible energy efficiency of $62.2 \%$ (corresponding to the aspirational values of $0.6 \mathrm{~V}$ overpotential and $95 \% \mathrm{FE}$ ) the cost of $24 / 7$ production is $\$ 355 / \mathrm{mt}, \$ 441 / \mathrm{mt}$ and $\$ 527 / \mathrm{mt}$ at $\Delta$ values of $\$ 10 / \mathrm{MWh}, \$ 20 / \mathrm{MWh}$ and $\$ 30 / \mathrm{MWh}$ respectively (columns 4-6). A greater savings is now achieved by taking advantage of dynamic electricity pricing since more energy is required to 
produce a given quantity of ammonia $\left[(5.37 / 0.62) \mathrm{MWh} / \mathrm{mt}-\mathrm{NH}_{3}\right]$. Operating only $85 \%$ of the time (corresponding to a cut-off of $\$ 27.5 / \mathrm{MWh}$ ), production costs that are 5-8\% lower can be achieved.

Even in less favorable scenarios the cost of ammonia production via ENR is not exorbitantly high. With an energy efficiency of only 39\% (corresponding, for example, to an overpotential of $1.2 \mathrm{~V}$ and $\mathrm{FE}=80 \%$ ) and assuming $\Delta=\$ 25 / \mathrm{MWh}$, ammonia production can be achieved at a cost of $\$ 676 / \mathrm{mt}$ with an operating-time percentage of $80 \%$ (column 7). (Note that at these lower FEs, substantial quantity of $\mathrm{H}_{2}$ is produced, which could have significant value, discussed below, partially offsetting the increased cost due to the "wasted" electrical current.) We also considered the possibility that the fixed cost (capital and operating costs) would be much higher than our estimates. Increasing this total by a factor of two, with an EE of $62 \%$ and $\Delta=\$ 25 / \mathrm{MWh}$, allows ammonia production at a total cost of $\$ 540 / \mathrm{mt}$, operating at $94 \%$ capacity (column 9 ). Conversely, lower fixed costs would allow the plant to take greater advantage of dynamic power pricing; decreasing fixed costs by a factor of two permits ammonia production at $\$ 411 / \mathrm{mt}$, operating at $70 \%$ capacity. It should be noted, however, that a greater quantity could be produced at an only slightly higher average cost (e.g. operating at $90 \%$ of capacity, the average cost of production from the additional $20 \%$ of capacity would be $\$ 433 / \mathrm{mt}^{-\mathrm{NH}_{3}}$, yielding a total average cost of $\$ 416 / \mathrm{mt}^{-\mathrm{NH}_{3}}$; Column 10); the actual optimum electricity price cut-off on any given day would presumably be dictated by ammonia prices.

The values in Table 6, as mentioned above, were obtained using electricity prices from the ERCOT West Hub which, offers the lowest average pricing of ERCOT Hubs/Loading-Zones. Variations between these Hubs/Zones, however, do not dramatically affect costs. The same analysis was conducted using pricing from the ERCOT Hub/Zone with highest average prices, the Houston Loading Zone, which offers an average price of $\$ 29.1 / \mathrm{MWh}, 30.5 \%$ greater than that of the West Hub (\$22.3/MWh). However, due to the contributions from fixed costs and power delivery, at $62 \% \mathrm{EE}$ and $\Delta=\$ 20 / \mathrm{MWh}$, for example, the cost of production when operating at $100 \%$ capacity is only $13 \%$ greater, $\$ 500 / \mathrm{mt}^{-\mathrm{NH}_{3}}$ vs. $\$ 441 / \mathrm{mt}^{-\mathrm{NH}_{3}}$ with West Hub pricing (see Appendix). Further, the higher average price is correlated with greater pricing variability; this would allow the plant to take greater advantage of dynamic pricing. Accordingly, the minimum total per-ton ammonia cost, using the pricing from the Houston Loading Zone, assuming 62\% EE and $\Delta=\$ 20 / \mathrm{MWh}$, is $\$ 440 / \mathrm{mt}^{-N_{3}}$, achieved at ca. $80 \%$ capacity. This is only $6.3 \%$ higher than the minimum price $(\$ 414 / \mathrm{mt})$ obtained with West Hub pricing under these conditions.

Although the focus of this paper is on comparing the cost of ammonia production via $\mathrm{H}-\mathrm{B}$, $\mathrm{E} / \mathrm{H}-\mathrm{B}$, and ENR, we note that the cost estimates projected in this study are well within the range of recent historical retail ammonia prices. For example, retail prices averaged $\$ 480 / \mathrm{mt}-\mathrm{NH}_{3}$ in the

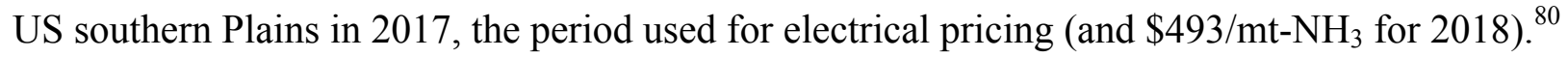
Wholesale prices, at the Gulf of Mexico, tend to be lower by about $\$ 200 / \mathrm{mt}_{-} \mathrm{NH}_{3},{ }^{80}$ but given the opportunities in decentralization offered by ENR, the local retail prices in agricultural areas may offer a better point of comparison. 


\section{4.d. Comparison of ENR and E/H-B economics.}

A comparison of Tables 3 and 5 reveals the differences in ammonia production costs between ENR and E/H-B assuming a fixed electricity price of \$50/MWh.

We assume that reduction of $\mathrm{H}^{+}$to give $\mathrm{H}_{2}$ in the E/H-B process will be more energy efficient than $\mathrm{N}_{2}$ reduction to give ammonia in ENR. Nevertheless, because of the capital and energy expenses associated with the H-B component, even at the greatest economy of scale, ammonia production via $\mathrm{E} / \mathrm{H}-\mathrm{B}$ is projected to be more costly than ENR at the aspirational EE of $62 \%$. This is illustrated, for a fixed energy cost of $\$ 50 / \mathrm{MWh}$, in Table 7 which summarizes the data in Tables 3 and 5. Note that the total electrical power required for E/H-B (electrolysis and H-B plant operation) is approximately equal to that required for nitrogen reduction via ENR; therefore any change in electricity prices will affect production costs of $\mathrm{E} / \mathrm{H}-\mathrm{B}$ and $\mathrm{ENR}$ equally in this scenario.

Table 7. Estimated costs of ammonia production $\left(\$ / \mathrm{mt}_{-} \mathrm{NH}_{3}\right)$ via ENR compared with $\mathrm{E} / \mathrm{H}-\mathrm{B}$ with accompanying $\mathrm{H}-\mathrm{B}$ plants of varying capacity, at a fixed benchmark electric power cost of $\$ 50 / \mathrm{MWh}$ (from Tables 3 and 5)

\begin{tabular}{|c|c|c|c|c|}
\hline & \multirow[b]{2}{*}{ ENR } & \multicolumn{3}{|c|}{ E/H-B } \\
\hline & & $\begin{array}{l}\text { Large H-B plant } \\
\text { (ca. } 2000 \mathrm{mt} / \text { day) }\end{array}$ & $\begin{array}{c}\text { Medium } \\
\text { H-B } \\
\text { plant } \\
\text { (545 } \\
\text { mt/day) }\end{array}$ & $\begin{array}{l}\text { Small H-B plant } \\
\text { (91 mt/day) }\end{array}$ \\
\hline $\begin{array}{l}\text { Electricity to produce } \mathrm{H}_{2} \\
\text { or } \mathrm{NH}_{3}\end{array}$ & $\$ 432$ & $\$ 441$ & $\$ 441$ & $\$ 441$ \\
\hline $\begin{array}{l}\text { Capital cost } \\
\text { (electrochemical stacks) }\end{array}$ & $\$ 35$ & $\$ 33$ & $\$ 33$ & $\$ 33$ \\
\hline $\begin{array}{l}\text { O\&M expenses } \\
\text { (electrolysis unit only) }\end{array}$ & $\$ 41$ & $\$ 41$ & $\$ 41$ & $\$ 41$ \\
\hline $\begin{array}{l}\text { Electricity to run } \\
\text { accompanying H-B plant }\end{array}$ & 0 & $\$ 67$ & $\$ 67$ & $\$ 67$ \\
\hline $\begin{array}{l}\text { Capital cost for H-B plant } \\
\text { and ASU unit }\end{array}$ & 0 & $\$ 32$ & $\$ 51$ & $\$ 66$ \\
\hline $\begin{array}{l}\text { O\&M expenses for } \mathrm{H}-\mathrm{B} \\
\text { plant }\end{array}$ & 0 & $\$ 13$ & $\$ 36$ & $\$ 77$ \\
\hline Total & $\$ 508$ & $\$ 627$ & $\$ 669$ & $\$ 725$ \\
\hline
\end{tabular}

Like ENR, E/H-B would allow exploitation of dynamic pricing of electrical energy, but to a lesser extent. Table 8 shows estimated costs of ammonia production via $\mathrm{E} / \mathrm{H}-\mathrm{B}$, with operation of the electrolyzer discontinued at various electricity costs using the same the approach as taken above for ENR (Table 6). The cost is calculated according to eq $14 .^{81}$ ( $\mathrm{PE}_{\mathrm{avg}}$ is the average price paid for electrical energy (per MWh) for 24/7 operation for the H-B plant.)

total cost $/ \mathrm{mt}^{-N_{3}}=(39.7 \mathrm{MWh})\left(\mathrm{PE}_{\text {cut }}+\Delta\right) /\left(\mathrm{EE}^{*} 5.632\right)+\mathrm{FC} / \mathrm{OT}+1.33 \mathrm{MWh}\left(\mathrm{PE}_{\mathrm{avg}}+\Delta\right)$ 
Table 8. Total cost (USD, energy plus fixed costs) per mt-NH $\mathrm{N}_{3}$ produced as a function of EE, electricity cost, capital and operating expenses, with varying electricity pricing cut-offs for operation using 2017 ERCOT real-time market prices (ERCOT West Hub), shown for ENR (62\% EE), and for E/H-B (80\% EE) from systems that include accompanying large- or medium-scale H-B plants.

\begin{tabular}{|c|c|c|c|c|c|c|c|c|c|c|c|}
\hline & & & \multicolumn{3}{|c|}{ ENR } & \multicolumn{3}{|c|}{ E/H-B (large H-B plant) ${ }^{\mathrm{h}}$} & \multicolumn{3}{|c|}{ E/H-B (medium H-B plant) ${ }^{\mathrm{i}}$} \\
\hline & & & 1 & 2 & 3 & 4 & 5 & 6 & 7 & 8 & 9 \\
\hline \multicolumn{3}{|r|}{ Energy Efficiency } & $62 \%$ & $62 \%$ & $62 \%$ & $80 \%$ & $80 \%$ & $80 \%$ & $80 \%$ & $80 \%$ & $80 \%$ \\
\hline & & $\Delta(\$ / M W h)^{\mathrm{a}}$ & 10 & 20 & 30 & 10 & 20 & 30 & 10 & 20 & 30 \\
\hline \multicolumn{3}{|c|}{ Fixed costs $^{\mathrm{b}}(\$ / \mathrm{mt})(24 / 7)$} & 76 & 76 & 76 & 119 & 119 & 119 & 161 & 161 & 161 \\
\hline \multirow[t]{2}{*}{$\begin{array}{c}\text { energy cost } \\
\text { cut-off } \\
\text { (\$/MWh) }\end{array}$} & $\begin{array}{c}\% \text { time } \\
\text { operating }^{d}\end{array}$ & $\begin{array}{l}\text { average energy } \\
\text { cost (\$/MWh) }\end{array}$ & \multicolumn{9}{|c|}{ Total cost (electricity plus fixed) $\left(\$ / \mathrm{MT}-\mathrm{NH}_{3}\right)$} \\
\hline & & & \multicolumn{3}{|c|}{ ENR } & \multicolumn{3}{|c|}{$\mathrm{E} / \mathrm{H}-\mathrm{B}$} & \multicolumn{3}{|c|}{$\mathrm{E} / \mathrm{H}-\mathrm{B}$} \\
\hline & 100 & 22.31 & 355 & 441 & 527 & 447 & 548 & 650 & 489 & 590 & 692 \\
\hline 43.7 & 97 & 19.44 & 332 & 419 & 505 & 425 & 527 & 628 & 468 & 570 & 671 \\
\hline 33.6 & 94 & 18.86 & 330 & 416 & 503 & 424 & 525 & 627 & 469 & 570 & 671 \\
\hline 30.3 & 90 & 18.29 & 328 & 415 & 501 & 425 & 526 & 627 & 471 & 573 & 674 \\
\hline 27.5 & 85 & 17.67 & 328 & 414 & 501 & 427 & 528 & 630 & 476 & 578 & 679 \\
\hline 24.8 & 80 & 17.14 & 329 & 415 & 502 & 431 & 532 & 634 & 483 & 585 & 686 \\
\hline 21.7 & 70 & 16.32 & 335 & 422 & 508 & 445 & 546 & 648 & 505 & 606 & 708 \\
\hline 20.0 & 50 & 14.52 & 363 & 450 & 536 & 497 & 598 & 700 & 581 & 682 & 784 \\
\hline 10.7 & 10 & 1.23 & 854 & 940 & 1027 & 1332 & 1433 & 1535 & 1752 & 1853 & 1955 \\
\hline \multicolumn{3}{|c|}{ per ton cost energy only $(24 / 7)^{f}$} & 193 & 193 & 193 & 226 & 226 & 226 & 226 & 226 & 226 \\
\hline \multicolumn{3}{|c|}{ per ton cost energy $+\Delta(24 / 7)^{\mathrm{g}}$} & 279 & 365 & 452 & 328 & 429 & 531 & 328 & 429 & 531 \\
\hline \multicolumn{3}{|c|}{ per ton fixed costs $(24 / 7)$} & 76 & 76 & 76 & 119 & 119 & 119 & 161 & 161 & 161 \\
\hline \multicolumn{3}{|c|}{ per ton total costs $(24 / 7)$} & 355 & 441 & 527 & 447 & 548 & 650 & 489 & 590 & 692 \\
\hline
\end{tabular}

a) $\Delta=$ difference between wholesale electricity price and price paid

b) Fixed costs (capital and operating expenses) per ton assuming full-time operation at capacity

c) Greatest wholesale electricity price at percent operating time indicated (i.e. pricing at percentile indicated)

d) Percent time operating, assuming full operation at indicated pricing level or lower

e) Average cost of energy during time operating

f) Energy cost (not including $\Delta$ ) per mt, full-time operation at capacity (including energy to run H-B plant for E/H-B)

g) Energy cost (including $\Delta$ ) per mt, full-time operation at capacity (including energy to run $\mathrm{H}-\mathrm{B}$ plant for E/H-B)

h) Associated H-B plant with capacity of ca. $2000 \mathrm{mt}-\mathrm{NH}_{3} /$ day (see Table 7)

i) Associated H-B plant with capacity of $545 \mathrm{mt}-\mathrm{NH}_{3} /$ day (see Table 7)

Selected results are shown in Table 8. (Results from Table 6 for ENR at $62 \%$ energy efficiency are shown in columns 1-3 of Table 8 for comparison.) Columns 4-6 show results assuming operation at a large scale (an accompanying $\mathrm{H}-\mathrm{B}$ plant with ca. $2000 \mathrm{mt}-\mathrm{NH}_{3} /$ day capacity) and values in columns 7-9 are obtained assuming a "medium" scale $\mathrm{H}-\mathrm{B}$ reactor (545 $\mathrm{mt}-\mathrm{NH}_{3}$ day), which is more commensurate with the size of the electrolysis unit used to calculate these value (50 $\mathrm{mt}-\mathrm{H}_{2} /$ day corresponding to $282 \mathrm{mt}-\mathrm{NH}_{3} /$ day).

These calculations show that E/H-B is not only intrinsically more costly than an efficient ENR process, but also does not benefit as greatly as ENR from pricing fluctuations because of higher (fixed) capital costs and (to a much smaller extent) because the electrically powered H-B plant must run continuously (assuming no $\mathrm{H}_{2}$ storage facility, the introduction of which would result in 
higher capital/fixed costs), regardless of electricity prices. ${ }^{82}$ Moreover, we note that the conclusion that $\mathrm{E} / \mathrm{H}-\mathrm{B}$ is not as potentially economical as ENR is reached in spite of two simplifying assumptions we have made that favor the assessment of E/H-B: (i) a $100 \%$ yield of $\mathrm{NH}_{3}$ from the synthesis process and (ii) the assumption that the smaller $\mathrm{H}-\mathrm{B}$ plants operate with the same energy efficiency as the largest plants.

\section{4.e. Alternative pathways for the reusing of $\mathrm{H}_{2}$ and its implications}

The energy efficiency estimated for the ENR process in the above analysis is a multiple of the Faradaic efficiency (FE) and a term accounting for overpotential (TE/TV). The plausible variability in FE is much greater than that of TE/TV. We consider that the latter term will likely range from 0.56 to 0.66 (corresponding to overpotentials of $0.6 \mathrm{~V}$ to $1.2 \mathrm{~V}$ ), and thus a variation of only $17 \%$. By contrast FE could in principle be any value up to $100 \%$ (values of FE ranging from $60 \%$ to $100 \%$ were used to obtain the per-mt costs shown in Table 6).

The term TE/TV represents (in an economic sense) "wasted energy" unless the resulting heat can be exploited. Any FE less than unity, however, does not necessarily represent "lost" energy because the primary competitive process is the reduction of $\mathrm{H}^{+}$to $\mathrm{H}_{2}$, which is a recoverable byproduct. Since the value of $\mathrm{H}_{2}$ is very dependent on the circumstances and location where it is produced, it is beyond the scope of this study to estimate the economic value of the $\mathrm{H}_{2}$. In the absence of a suitable market, perhaps the most obvious use of the $\mathrm{H}_{2}$ in the context of ENR is to generate electricity that would be "recycled" to further increase the yield of $\mathrm{NH}_{3}$ per unit electrical energy purchased externally. One could envision a separate hydrogen fuel cell generating electric power, or alternatively mixing the $\mathrm{H}_{2}$ into the feed at the anode of the ENR cell, thereby lowering the oxidation potential.

An alternative use of $\mathrm{H}_{2}$ byproduct of ENR would be for the air separation required to generate $\mathrm{O}_{2}$-free $\mathrm{N}_{2}$ for the electrocatalytic reaction. The $\mathrm{N}_{2} / \mathrm{O}_{2}$ molar ratio of air is 3.73 , and the ratio of electrons required to reduce $\mathrm{O}_{2}$ relative to $\mathrm{N}_{2}$ is $4: 6$. From these values, one can calculate that $15 \%$ of the total electric current would afford enough $\mathrm{H}_{2}$ to combust all the $\mathrm{O}_{2}$ in an air feed, i.e. if $\mathrm{FE} \leq$ 0.85 the system would produce enough $\mathrm{H}_{2}$ to consume all the $\mathrm{O}_{2}$ in the air feed. This could be an advantage over a typical air-separation module, with much lower capital and operations cost.

If the FE for ENR were above $85 \%$, the smaller available quantities of $\mathrm{H}_{2}$ could be used to reduce $\mathrm{O}_{2}$ after an initial crude air-separation process. Likewise, even if $\mathrm{H}_{2}$ sufficient to reduce all $\mathrm{O}_{2}$ in the air feed were produced, it might be determined that an initial low-cost crude separation, followed by treatment with $\mathrm{H}_{2}$, would permit more $\mathrm{H}_{2}$ to be used for a more valuable application. 


\section{4.f. Comparison of economics of ENR with fossil-fuel-based H-B}

The projected costs for ammonia production by ENR shown in Table 6 (as well as those for E/H-B in Table 8) are based on prices for electrical power that is obtained in part from renewable sources, but primarily from fossil fuels. The primary energy mix for ERCOT in 2017 consisted of natural gas (39\%), coal (32\%), wind (17\%), and nuclear (11\%). ${ }^{83-84}$

The high capital cost of a H-B plant notwithstanding, if the source of electrical power for ENR (or any other electrochemical process) is primarily natural gas, the cost of such ammonia production will presumably always be greater than that of large-scale natural-gas-based $\mathrm{H}-\mathrm{B}$ production. The energy loss involved in the overall ENR process in generating electricity from natural gas, and then in using that electrical power to reduce $\mathrm{N}_{2}$, will presumably outweigh both capital costs and energy loss of a modern H-B plant. This is reflected in the estimated production costs for ENR and H-B for the same time period (and thus at the same price of natural gas); ENR production costs, using ERCOT pricing and taking advantage of fluctuating prices (Table 6), are estimated to be at least $\$ 150$ per mt- $\mathrm{NH}_{3}$ above $\mathrm{H}-\mathrm{B}$ costs in the case of a large-scale H-B plant (Table 2).

The low cost, to the producer, of ammonia via natural-gas-based H-B notwithstanding, this process has major implications for global greenhouse gas (GHG) emissions (section 2). ${ }^{85}$ As noted above, production based on natural gas feedstock results in at least $1.33 \mathrm{mt}-\mathrm{CO}_{2}$ produced per mt$\mathrm{NH}_{3}$. Including the cost of this negative externality yields a significant increase in the total (social and private) cost of ammonia produced via a natural-gas-based $\mathrm{H}-\mathrm{B}$ process relative to production via ENR based on carbon-free electricity. The magnitude of this effect of course depends on the social cost of carbon, estimates of which vary greatly. A detailed survey by Pindyck yields a mean value of $\$ 174 / \mathrm{mt}-\mathrm{CO}_{2}$ based on responses from economists, and $\$ 316 / \mathrm{mt}-\mathrm{CO}_{2}$ based on responses from climate scientists (corresponding to $\$ 231 / \mathrm{mt}^{-N_{3}}$ and $\$ 421 / \mathrm{mt}^{-N_{3}}$, respectively) with an overall value of $\$ 291 / \mathrm{mt}_{-}-\mathrm{CO}_{2}\left(\$ 387 / \mathrm{mt}_{-} \mathrm{NH}_{3}\right)$ based on responses from all experts surveyed. ${ }^{86}$ Ricke et al. in a recent extensive study determined the median estimated social cost to be $\$ 417 / \mathrm{mt}$ $\mathrm{CO}_{2}\left(\$ 555 / \mathrm{mt}^{-\mathrm{NH}_{3}}\right)$, with $\$ 177-\$ 805\left(\$ 235-\$ 1070 / \mathrm{mt}^{-\mathrm{NH}_{3}}\right)$ representing $66 \%$ confidence intervals. ${ }^{87}$ Additionally, natural gas use is associated with methane emissions (primarily from natural gas extraction). Emissions of methane associated with H-B ammonia production equal $0.35 \%$ of $\mathrm{CO}_{2}$ emissions, and the 100 -year Global Warming Potential of methane is 28 times that of $\mathrm{CO}_{2} ;{ }^{88}$ thus associated methane emissions may be considered to have an additional social cost equal to $10 \%$ that of the $\mathrm{CO}_{2}$ emissions.

ENR would therefore become increasingly cost competitive with H-B as the externalities of $\mathrm{CO}_{2}$ emissions are incorporated (directly or indirectly) into the cost of ammonia produced from natural gas. This may occur most directly in the form of a carbon tax or a cap-and-trade system. Alternatively, renewably produced ammonia could be favored by subsidies or other measures commensurate with the value of avoided $\mathrm{CO}_{2}$ emissions. More extreme measures are also possible such as legislation requiring a carbon-free or low-carbon economy; the state of New York, for example, has recently passed a legal resolution to achieve the former goal by $2050{ }^{89}$ 
Decreases in the cost of renewable energy, which are widely projected, ${ }^{90-92}$ will of course also favor an ENR approach to ammonia. Levelized costs of electricity from both onshore wind and solar photovoltaic are projected to be ca. $\$ 50 / \mathrm{MWh}$ for sources scheduled to go online in $2023,{ }^{93}$ with large scale solar photovoltaic power selling for as little as $\$ 20 / \mathrm{MWh}$ by that year. ${ }^{94}$

Conversely, it is far from certain that natural gas prices will remain at current, historically low, level of ca. \$3/MBTU. In the AEO2019 reference case of the U.S. EIA, natural gas is projected to rise to $\$ 5$ per MBTU by 2050 with scenarios at two extremes giving respective prices of slightly over $\$ 3$ and slightly over $\$ 8$ per MBTU (all prices in 2018 dollars). ${ }^{90}$

In sum, even if only the low end of the estimated ranges of social costs of $\mathrm{CO}_{2}$ emissions is incorporated into the cost of fossil-fuel-based H-B, then renewable-power-based ENR at ca. $60 \%$ energy efficiency would already be competitive. Alternatively or in parallel, limitations on GHGemissions could favor ENR over H-B. Additionally, the economic advantage of ENR will only increase as renewable energy costs will presumably decrease, ${ }^{90-92}$ and natural gas prices may significantly increase. ${ }^{90}$ Moreover, as the market penetration of renewables continues to grow, ${ }^{92-93 \text {, }}$ ${ }^{95-97}$ its value to the electric grid decreases ${ }^{98}$ due to issues of intermittency; therefore, consumers of electricity with flexible demand will have increasing opportunity to purchase power at a price below the 24/7 average. Finally, the cost of any energy loss due to Faradaic inefficiency in a ENR process will be offset in some part by the value of the hydrogen by-product.

Although there is far too much uncertainty (particularly, but not only, in the social cost of carbon) to allow a comparison of the economics of $\mathrm{H}-\mathrm{B}$ with $\mathrm{ENR}$ or $\mathrm{E} / \mathrm{H}-\mathrm{B}$ with any significant degree of precision, a crude estimate of the potential relative economics may be useful. For this purpose we employ values projected for 2040 (in present dollars) for the total-system levelized cost of electricity (including transmission) from onshore wind $(\$ 40.2 / \mathrm{MWh}),{ }^{99}$ the mid-range 2040 projected price of natural gas (\$4.1/MBTU), ${ }^{90}$ and Pindyck's mean value for the social cost of carbon ( $\$ 291 / \mathrm{mt}-\mathrm{CO}_{2}$ corresponding to $\left.\$ 387 / \mathrm{mt}-\mathrm{NH}_{3}\right)$. For the purposes of this crude comparison we neglect the ability to exploit dynamic pricing in the case of ENR or E/H-B. The results (Table 9) highlight that the economic competitiveness of ammonia production via ENR relative to H-B is very strongly dependent on whether (and to what extent) the social cost of carbon emissions is incorporated into the cost of production via $\mathrm{H}-\mathrm{B}$. 
Table 9. Estimated costs, projected for 2040 , of ammonia production $\left(\$ / \mathrm{mt}-\mathrm{NH}_{3}\right)$ via gas-based $\mathrm{H}-\mathrm{B}$ (full-scale plant), ENR, and E/H-B with accompanying H-B plants of varying capacity. Projected prices for electricity and natural gas are $\$ 40.2 / \mathrm{MWh}^{99}$ (fixed) and $\$ 4.1 / \mathrm{MBTU}^{90}$ respectively. Social cost of carbon emissions is the mean value reported in reference 86 .

\begin{tabular}{|c|c|c|c|c|c|}
\hline & \multicolumn{2}{|c|}{$\begin{array}{c}\text { H-B } \\
\text { Large H-B plant (2000 mt/day) }\end{array}$} & \multirow[b]{2}{*}{ ENR } & \multicolumn{2}{|c|}{ E/H-B } \\
\hline & $\begin{array}{l}\text { not including } \\
\text { SCC }\end{array}$ & including SCC & & $\begin{array}{l}\text { Large H-B plant } \\
(2000 \mathrm{mt} / \text { day })^{\mathrm{a}}\end{array}$ & $\begin{array}{l}\text { Small H-B plant } \\
(91 \mathrm{mt} / \mathrm{day})^{\mathrm{a}}\end{array}$ \\
\hline Electricity to produce $\mathrm{H}_{2}$ or $\mathrm{NH}_{3}{ }^{\mathrm{b}}$ & 0 & 0 & $\$ 347$ & $\$ 354$ & $\$ 354$ \\
\hline Capital cost (electrochemical stacks) & 0 & 0 & $\$ 35$ & $\$ 33$ & $\$ 33$ \\
\hline O\&M expenses (electrolysis unit only) & 0 & 0 & $\$ 41$ & $\$ 41$ & $\$ 41$ \\
\hline $\begin{array}{l}\text { Electricity to run accompanying H-B } \\
\text { plant }\end{array}$ & 0 & 0 & 0 & $\$ 42$ & $\$ 42$ \\
\hline Capital cost for H-B plant & $\$ 55$ & $\$ 55$ & 0 & $\$ 32$ & $\$ 66$ \\
\hline O\&M expenses for $\mathrm{H}-\mathrm{B}$ plant & $\$ 22$ & $\$ 22$ & 0 & $\$ 13$ & $\$ 77$ \\
\hline Natural gas & $\$ 124$ & $\$ 124$ & 0 & 0 & 0 \\
\hline Social cost of carbon emissions & - & $\$ 387$ & 0 & 0 & 0 \\
\hline Total & $\$ 201$ & $\$ 588$ & $\$ 423^{c}$ & $\$ 515^{c}$ & $\$ 613^{c}$ \\
\hline
\end{tabular}

a) Cost for H-B plant for E/H-B assumed to equal $58 \%$ of costs of full gas-based $\mathrm{H}-\mathrm{B}$ plant (large or small).

b) $62 \% \mathrm{EE}$ and $80 \% \mathrm{EE}$ assumed for ENR and $\mathrm{E} / \mathrm{H}-\mathrm{B}$ respectively.

c) Costs would presumably be lowered somewhat by taking advantage of dynamic electricity pricing.

\section{Concluding remarks}

The goal of this paper is to break down the ENR cost structure and allow comparison with conventional $\mathrm{H}-\mathrm{B}$ and with $\mathrm{E} / \mathrm{H}-\mathrm{B}$ alternatives. The analysis drew from work on hydrogen production (the $\mathrm{H} 2 \mathrm{~A}$ project) to predict the capital costs expected to be associated with ENR.

Unsurprisingly, the cost of electricity is predicted to be the major determinant of the cost of ammonia production via ENR. We quantify the potential decrease of the levelized cost of ammonia production that is obtained by conducting plant operation only below various prices of electric power, and at various levels of electrical efficiency and fixed (capital and operating) costs.

An ENR process operating at our aspirational levels of $\mathrm{FE}$ and overpotential is shown here to be intrinsically more economical than the primary carbon-free alternative, the electrolysis of water followed by the Haber-Bosch process (E-H/B). The reduction potential of $\mathrm{N}_{2}$ is slightly more favorable than that of $\mathrm{H}^{+},{ }^{76}$ corresponding to a theoretical energy requirement ca. $7.5 \%$ less for the formation of $\mathrm{NH}_{3}$ relative to the formation of the $\mathrm{H}_{2}$ required for hydrogenation of $\mathrm{N}_{2}$. Even more importantly, ENR does not require the energy consumption and high capital costs of an accompanying $\mathrm{H}-\mathrm{B}$ plant required by $\mathrm{E} / \mathrm{H}-\mathrm{B}$. Thus, even at our benchmarked $62 \%$ level of energy efficiency, the ENR process would be significantly more economical than E/H-B with electrolysis of water at $80 \%$ energy efficiency. Moreover, the less capital-intensive cost structure of ENR is particularly favored by volatility in electrical pricing. Likewise, in addition to the greater ability to respond to the pricing of electrical power, ENR would also provide more opportunity to 
discontinue and resume production according to fluctuations in ammonia pricing or demand. Lastly, removing the need for a H-B plant also allows a much greater degree of decentralization which potentially has benefits for farming even in areas that are well connected to infrastructure, and much more so for those that are not.

Nitrogen fixation is critical to the agricultural production necessary to feed humanity and is potentially of tremendous value for the storage, transportation, and consumption of renewable energy. But while the cost to the producer of conventional natural-gas-based $\mathrm{H}-\mathrm{B}$ production is generally quite low, its combined social and private cost is very high if typical estimates of social costs of GHG emission are taken into account. These costs are expected to be increasingly reflected in taxes and/or regulations on emissions. In addition to the social cost of GHG emissions, the reliance on fossil fuels also results in vulnerability to volatility in global market prices and a complex intersection with the geo-political landscape. ${ }^{100}$ Conversely, as the cost of renewable (carbon-free) energy continues to decline, methods based on it for ammonia production become economically more attractive.

At this time, E/H-B is the only technology that is efficient enough to feasibly replace $\mathrm{H}-\mathrm{B}$ on the scale necessary for fertilizer production. The results of this study, however, indicates that the development of a feasibly efficient ENR process is the more desirable solution to this long-term need. The potentially lower production cost via ENR may suggest that it is also the only process that could take practical advantage of the opportunities that nitrogen reduction offers for the storage and transportation of energy. It must be emphasized that the current state of ENR technology is still far from economically feasible for fertilizer production, and even less so for economically viable energy storage. Based on fundamental considerations illuminated in this work, however, we conclude that development of an efficient ENR technology is a goal with enormous potential reward.

\section{References}

(1) Searchinger, T.; Hanson, C.; Ranganathan, J.; Lipinski, B.; Waite, R.; Winterbottom, R.; Dinshaw, A.; Heimlich,

R., The great balancing act: installment 1 of creating a sustainable food future. World Resources Institute 2013.

(2) "The future of food and agriculture - Trends and challenges." Food and Agriculture Organization of the United Nations (FAO). Rome, 2017 http://www.fao.org/3/a-i6583e.pdf

(3) Smil, V., Nitrogen cycle and world food production. World Agriculture 2011, 2, 9-13.

(4) Catalytic Ammonia Synthesis, Fundamentals and Practice; Jennings, J. R., Ed. Springer US: 1991.

(5) Smil, V., Enriching the Earth: Fritz Haber, Carl Bosch, and the Transformation of World Food Production. MIT Press: Cambridge, MA, 2004.

(6) Erisman, J. W.; Sutton, M. A.; Galloway, J.; Klimont, Z.; Winiwarter, W., How a century of ammonia synthesis changed the world Nat. Geosci. 2008, 1, 636-639.

(7) Pattabathula, V.; Richardson, J., Introduction to Ammonia Production. CEP Magazine September, $2016,2016$.

(8) "Ammonia Market 2018 Outlook to 2022" Reuters VCNewsNetwork, 5 September 2018

https:/www.reuters.com/brandfeatures/venture-capital/article?id=49951 (retrieved June 30, 2019)

(9) Morgan, E. R. Techno-Economic Feasibility Study of Ammonia Plants Powered by Offshore Wind. PhD, University of Massachusetts Amherst, Open Access Dissertations. 697, 2013.

(10) Frattini, D.; Cinti, G.; Bidini, G.; Desideri, U.; Cioffi, R.; Jannelli, E., A system approach in energy evaluation of different renewable energies sources integration in ammonia production plants Renewable Energy 2016, 99, $472-482$.

(11) Noelker, K.; Ruether, J., Low Energy Consumption Ammonia Production: Baseline Energy Consumption, Options for Energy Optimization. In Nitrogen + Syngas Conference, Duesseldorf, 2011. 
(12) Rafiqul, I.; Weber, C.; Lehmann, B.; Voss, A., Energy efficiency improvements in ammonia productionperspectives and uncertainties Energy 2005, 30, 2487-2504.

(13) Tallaksen, J.; Bauer, F.; Hulteberg, C.; Reese, M.; Ahlgren, S., Nitrogen fertilizers manufactured using wind power: greenhouse gas and energy balance of community-scale ammonia production J. Clean. Prod. 2015, 107, 626635.

(14) Churchard, A. J.; Banach, E.; Borgschulte, A.; Caputo, R.; Chen, J.-C.; Clary, D.; Fijalkowski, K. J.; Geerlings, H.; Genova, R. V.; Grochala, W.; Jaroń, T.; Juanes-Marcos, J. C.; Kasemo, B.; Kroes, G.-J.; Ljubić, I.; Naujoks, N.; Nørskov, J. K.; Olsen, R. A.; Pendolino, F.; Remhof, A.; Románszki, L.; Tekin, A.; Vegge, T.; Zäch, M.; Züttel, A., A multifaceted approach to hydrogen storage Phys. Chem. Chem. Phys. 2011, 13, 16955-16972.

(15) Aziz, M.; Oda, T.; Morihara, A.; Kashiwagi, T., Combined nitrogen production, ammonia synthesis, and power generation for efficient hydrogen storage Energy Procedia 2017, 143, 674-679.

(16) Giddey, S.; Badwal, S. P. S.; Munnings, C.; Dolan, M., Ammonia as a Renewable Energy Transportation Media ACS Sustain. Chem. Eng. 2017, 5, 10231-10239.

(17) Valera-Medina, A.; Xiao, H.; Owen-Jones, M.; David, W. I. F.; Bowen, P. J., Ammonia for power Progress in Energy and Combustion Science 2018, 69, 63-102.

(18) Service, R. F., Liquid sunshine Science (Washington, DC, U. S.) 2018, 361, 120-123.

(19) Yapicioglu, A.; Dincer, I., A review on clean ammonia as a potential fuel for power generators Renew. Sust. Energy Rev. 2019, 96-108.

(20) Juangsa, F. B.; Aziz, M., Integrated system of thermochemical cycle of ammonia, nitrogen production, and power generation Int. J. Hydrog. Energy 2019, 44, 17525-17534.

(21) Bicer, Y.; Dincer, I., Exergoeconomic analysis and optimization of a concentrated sunlight-driven integrated photoelectrochemical hydrogen and ammonia production system Int. J. Hydrog. Energy 2019, 44, 18875-18890.

(22) Bargiacchi, E.; Antonelli, M.; Desideri, U., A comparative assessment of Power-to-Fuel production pathways Energy 2019, 183, 1253-1265.

(23) Suryanto, B. H. R.; Du, H.-L.; Wang, D.; Chen, J.; Simonov, A. N.; MacFarlane, D. R., Challenges and prospects in the catalysis of electroreduction of nitrogen to ammonia Nat. Catal. 2019, 2, 290-296.

(24) Foster, S. L.; Bakovic, S. I. P.; Duda, R. D.; Maheshwari, S.; Milton, R. D.; Minteer, S. D.; Janik, M. J.; Renner, J. N.; Greenlee, L. F., Catalysts for nitrogen reduction to ammonia Nat. Catal. 2018, 1, 490-500.

(25) Chen, J. G.; Crooks, R. M.; Seefeldt, L. C.; Bren, K. L.; Bullock, R. M.; Darensbourg, M. Y.; Holland, P. L.; Hoffman, B.; Janik, M. J.; Jones, A. K.; Kanatzidis, M. G.; King, P.; Lancaster, K. M.; Lymar, S. V.; Pfromm, P.; Schneider, W. F.; Schrock, R. R., Beyond fossil fuel-driven nitrogen transformations Science 2018, 360 , eaar6611. (26) Singh, A. R.; Rohr, B. A.; Schwalbe, J. A.; Cargnello, M.; Chan, K.; Jaramillo, T. F.; Chorkendorff, I.; Nørskov, J. K., Electrochemical Ammonia Synthesis-The Selectivity Challenge ACS Catal. 2017, 7, 706-709.

(27) Montoya, J. H.; Tsai, C.; Vojvodic, A.; Nørskov, J. K., The Challenge of Electrochemical Ammonia Synthesis: A New Perspective on the Role of Nitrogen Scaling Relations ChemSusChem 2015, 8, 2180-2186.

(28) Yang, D.; Chen, T.; Wang, Z., Electrochemical reduction of aqueous nitrogen $\left(\mathrm{N}_{2}\right)$ at a low overpotential on (110)-oriented Mo nanofilm J. Mater. Chem. A 2017, 5, 18967-18971.

(29) Zhang, L.; Ji, X.; Ren, X.; Ma, Y.; Shi, X.; Tian, Z.; Asiri, A. M.; Chen, L.; Tang, B.; Sun, X., Electrochemical Ammonia Synthesis via Nitrogen Reduction Reaction on a $\mathrm{MoS}_{2}$ Catalyst: Theoretical and Experimental Studies $A d v$. Mater. 2018, 30, 1800191.

(30) Han, J.; Ji, X.; Ren, X.; Cui, G.; Li, L.; Xie, F.; Wang, H.; Li, B.; Sun, X., MoO 3 nanosheets for efficient electrocatalytic $\mathrm{N}_{2}$ fixation to $\mathrm{NH}_{3} J$. Mater. Chem. A 2018, 6, 12974-12977.

(31) Ren, X.; Cui, G.; Chen, L.; Xie, F.; Wei, Q.; Tian, Z.; Sun, X., Electrochemical $\mathrm{N}_{2}$ fixation to $\mathrm{NH}_{3}$ under ambient conditions: $\mathrm{Mo}_{2} \mathrm{~N}$ nanorod as a highly efficient and selective catalyst Chem. Commun. 2018, 54, 8474-8477.

(32) Zhang, L.; Ji, X.; Ren, X.; Luo, Y.; Shi, X.; Asiri, A. M.; Zheng, B.; Sun, X., Efficient Electrochemical N 2 Reduction to $\mathrm{NH}_{3}$ on MoN Nanosheets Array under Ambient Conditions ACS Sustain. Chem. Eng. 2018, 6, 95509554.

(33) Suryanto, B. H. R.; Kang, C. S. M.; Wang, D.; Xiao, C.; Zhou, F.; Azofra, L. M.; Cavallo, L.; Zhang, X.; MacFarlane, D. R., Rational Electrode-Electrolyte Design for Efficient Ammonia Electrosynthesis under Ambient Conditions ACS Energy Lett. 2018, 3, 1219-1224.

(34) Li, X.; Li, T.; Ma, Y.; Wei, Q.; Qiu, W.; Guo, H.; Shi, X.; Zhang, P.; Asiri, A. M.; Chen, L.; Tang, B.; Sun, X., Boosted Electrocatalytic $\mathrm{N}_{2}$ Reduction to $\mathrm{NH}_{3}$ by Defect-Rich $\mathrm{MoS}_{2}$ Nanoflower Adv. Energy Mater. 2018, 8 , 1801357.

(35) Lv, C.; Yan, C.; Chen, G.; Ding, Y.; Sun, J.; Zhou, Y.; Yu, G., An Amorphous Noble-Metal-Free Electrocatalyst that Enables Nitrogen Fixation under Ambient Conditions Angew. Chem., Intl. Ed. 2018, 6073-6076.

(36) Shi, M.-M.; Bao, D.; Wulan, B.-R.; Li, Y.-H.; Zhang, Y.-F.; Yan, J.-M.; Jiang, Q., Au Sub-Nanoclusters on TiO 2 toward Highly Efficient and Selective Electrocatalyst for $\mathrm{N}_{2}$ Conversion to $\mathrm{NH}_{3}$ at Ambient Conditions Adv. Mater. 2017, 29, 1606550 . 
(37) Li, S.-J.; Bao, D.; Shi, M.-M.; Wulan, B.-R.; Yan, J.-M.; Jiang, Q., Amorphizing of Au Nanoparticles by CeO ${ }_{\text {- }}$ RGO Hybrid Support towards Highly Efficient Electrocatalyst for $\mathrm{N}_{2}$ Reduction under Ambient Conditions $A d v$. Mater. 2017, 29, 1700001.

(38) Bao, D.; Zhang, Q.; Meng, F.-L.; Zhong, H.-X.; Shi, M.-M.; Zhang, Y.; Yan, J.-M.; Jiang, Q.; Zhang, X.-B., Electrochemical Reduction of $\mathrm{N}_{2}$ under Ambient Conditions for Artificial $\mathrm{N}_{2}$ Fixation and Renewable Energy Storage Using $\mathrm{N}_{2} / \mathrm{NH}_{3}$ Cycle Adv. Mater. 2017, 29, 1604799.

(39) Kong, J.; Lim, A.; Yoon, C.; Jang, J. H.; Ham, H. C.; Han, J.; Nam, S.; Kim, D.; Sung, Y.-E.; Choi, J.; Park, H. S., Electrochemical Synthesis of $\mathrm{NH}_{3}$ at Low Temperature and Atmospheric Pressure Using a $\gamma-\mathrm{Fe}_{2} \mathrm{O}_{3}$ Catalyst $A C S$ Sustain. Chem. Eng. 2017, 5, 10986-10995.

(40) Chen, S.; Perathoner, S.; Ampelli, C.; Mebrahtu, C.; Su, D.; Centi, G., Electrocatalytic Synthesis of Ammonia at Room Temperature and Atmospheric Pressure from Water and Nitrogen on a Carbon-Nanotube-Based Electrocatalyst Angew. Chem., Intl. Ed. 2017, 56, 2699-2703.

(41) Kyriakou, V.; Garagounis, I.; Vasileiou, E.; Vourros, A.; Stoukides, M., Progress in the Electrochemical Synthesis of Ammonia Catal. Today 2017, 286, 2-13.

(42) Liu, Q.; Zhang, X.; Zhang, B.; Luo, Y.; Cui, G.; Xie, F.; Sun, X., Ambient $\mathrm{N}_{2}$ fixation to $\mathrm{NH}_{3}$ electrocatalyzed by a spinel $\mathrm{Fe}_{3} \mathrm{O}_{4}$ nanorod Nanoscale 2018, 10, 14386-14389.

(43) Han, J.; Liu, Z.; Ma, Y.; Cui, G.; Xie, F.; Wang, F.; Wu, Y.; Gao, S.; Xu, Y.; Sun, X., Ambient N $\mathrm{N}_{2}$ fixation to $\mathrm{NH}_{3}$ at ambient conditions: Using $\mathrm{Nb}_{2} \mathrm{O}_{5}$ nanofiber as a high-performance electrocatalyst Nano Energy 2018, 52, 264270 .

(44) Liu, Y.; Su, Y.; Quan, X.; Fan, X.; Chen, S.; Yu, H.; Zhao, H.; Zhang, Y.; Zhao, J., Facile Ammonia Synthesis from Electrocatalytic N2 Reduction under Ambient Conditions on N-Doped Porous Carbon ACS Catal. 2018, 8, 11861191.

(45) Lee, H. K.; Koh, C. S. L.; Lee, Y. H.; Liu, C.; Phang, I. Y.; Han, X.; Tsung, C.-K.; Ling, X. Y., Favoring the unfavored: Selective electrochemical nitrogen fixation using a reticular chemistry approach Science Advances 2018, 4 , eaar3208.

(46) Kugler, K.; Luhn, M.; Schramm, J. A.; Rahimi, K.; Wessling, M., Galvanic deposition of Rh and Ru on randomly structured Ti felts for the electrochemical $\mathrm{NH}_{3}$ synthesis Phys. Chem. Chem. Phys. 2015, 17, 3768-3782.

(47) Kordali, V.; Kyriacou, G.; Lambrou, C., Electrochemical synthesis of ammonia at atmospheric pressure and low temperature in a solid polymer electrolyte cell Chem. Commun. 2000, 1673-1674.

(48) Wang, J.; Yu, L.; Hu, L.; Chen, G.; Xin, H.; Feng, X., Ambient ammonia synthesis via palladium-catalyzed electrohydrogenation of dinitrogen at low overpotential Nat. Commun. 2018, 9, 1795.

(49) Song, Y.; Johnson, D.; Peng, R.; Hensley, D. K.; Bonnesen, P. V.; Liang, L.; Huang, J.; Yang, F.; Zhang, F.; Qiao, R.; Baddorf, A. P.; Tschaplinski, T. J.; Engle, N. L.; Hatzell, M. C.; Wu, Z.; Cullen, D. A.; Meyer, H. M.; Sumpter, B. G.; Rondinone, A. J., A physical catalyst for the electrolysis of nitrogen to ammonia Science Advances 2018, 4, e1700336.

(50) Qiu, W.; Xie, X.-Y.; Qiu, J.; Fang, W.-H.; Liang, R.; Ren, X.; Ji, X.; Cui, G.; Asiri, A. M.; Cui, G.; Tang, B.; Sun, X., High-performance artificial nitrogen fixation at ambient conditions using a metal-free electrocatalyst $N a t$. Commun. 2018, 9, 3485 .

(51) Abghoui, Y.; Garden, A. L.; Hlynsson, V. F.; Bjoergvinsdottir, S.; Olafsdottir, H.; Skulason, E., Enabling electrochemical reduction of nitrogen to ammonia at ambient conditions through rational catalyst design Phys. Chem. Chem. Phys. 2015, 17, 4909-4918.

(52) Ren, X.; Zhao, J.; Wei, Q.; Ma, Y.; Guo, H.; Liu, Q.; Wang, Y.; Cui, G.; Asiri, A. M.; Li, B.; Tang, B.; Sun, X., High-Performance $\mathrm{N}_{2}$-to- $\mathrm{NH}_{3}$ Conversion Electrocatalyzed by $\mathrm{Mo}_{2} \mathrm{C}$ Nanorod ACS Cent. Sci. 2019, 5, $116-121$.

(53) Ren, S.; Joulié, D.; Salvatore, D.; Torbensen, K.; Wang, M.; Robert, M.; Berlinguette, C. P., Molecular electrocatalysts can mediate fast, selective $\mathrm{CO}_{2}$ reduction in a flow cell Science 2019, 365, 367.

(54) Andersson, J.; Lundgren, J., Techno-economic analysis of ammonia production via integrated biomass gasification Applied Energy 2014, 130, 484-490.

(55) Bañares-Alcántara, R.; III, G. D.; Fiaschetti, M.; Grünewald, P.; Lopez, J. n. M.; Tsang, E.; Yang, A.; Ye, L.; Zhao, S. Analysis of Islanded Ammonia-based Energy Storage Systems; University of Oxford: 2015.

(56) Dana, A. G.; Elishav, O.; Bardow, A.; Shter, G. E.; Grader, G. S., Nitrogen-Based Fuels: A Power-to-Fuel-toPower Analysis Angew. Chem., Intl. Ed. 2016, 55, 8798-8805.

(57) Elishav, O.; Lewin, D. R.; Shter, G. E.; Grader, G. S., The nitrogen economy: Economic feasibility analysis of nitrogen-based fuels as energy carriers Applied Energy 2017, 185, Part 1, 183-188.

(58) Wang, L.; Xia, M.; Wang, H.; Huang, K.; Qian, C.; Maravelias, C. T.; Ozin, G. A., Greening Ammonia toward the Solar Ammonia Refinery Joule 2018, 2, 1055-1074.

(59) Ikäheimo, J.; Kiviluoma, J.; Weiss, R.; Holttinen, H., Power-to-ammonia in future North European 100 \% renewable power and heat system Int. J. Hydrog. Energy 2018, 43, 17295-17308.

(60) Andersson, J.; Grönkvist, S., Large-scale storage of hydrogen Int. J. Hydrog. Energy 2019, 44, 11901-11919. 
(61) Dutta, G.; Mitra, K., A literature review on dynamic pricing of electricity J. Oper. Res. Soc. 2017, 68, 1131-1145.

(62) Denholm, P.; Hand, M., Grid flexibility and storage required to achieve very high penetration of variable renewable electricity Energy Policy 2011, 39, 1817-1830.

(63) Lund, P. D.; Lindgren, J.; Mikkola, J.; Salpakari, J., Review of energy system flexibility measures to enable high levels of variable renewable electricity Renew. Sust. Energy Rev. 2015, 45, 785-807.

(64) "Feeding the Earth, Energy Efficiency and $\mathrm{CO}_{2}$ emissions in ammonia production. Dec 2009" International

Fertilizer Industry Association.

https://www.fertilizer.org/images/Library Downloads/2009 IFA energy efficiency.pdf

(65) Smith, A. R.; Klosek, J., A review of air separation technologies and their integration with energy conversion processes Fuel Process. Technol. 2001, 70, 115-134.

(66) Industrial Efficiency Technology Database, Ammonia Benchmarks, http://ietd.iipnetwork.org/content/ammonia benchmarks (downloaded 2 June, 2019)

(67) Bartels, J. R. "A feasibility study of implementing an Ammonia Economy” Iowa State University - Digital Repository, 2008. http://lib.dr.iastate.edu/etd/11132/

(68) Producer Price Index, Construction machinery mfg - PCU333120333120, Bureau of Labor Statistics, annual average prices 2007-2017) https://data.bls.gov/cgi-bin/surveymost?pc (retrieved June 30, 2019)

(69) For examples of smaller plants: (a) A 600 short-ton-per-day plant was reported to be built in Rock Springs, WY for a cost of $\$ 350 \mathrm{M}$, or $\$ 643,000$ per MT- $\mathrm{NH}_{3} /$ day capacity. Brown, T. Ammonia Industry "Rock Springs, WY Simplot" 13 January, 2014: https://ammoniaindustry.com/rock-springs-wy-simplot/ (b) A 331-short-ton-per-day plant is planned for completion in Iowa in 2020 at a cost of $\$ 220 \mathrm{M}$ or $\$ 730,000$ per MT- $\mathrm{NH}_{3} /$ day capacity. Brown, T. Ammonia Industry "Garner, IA — Greenfield Nitrogen" 14 May, 2018: https://ammoniaindustry.com/garner-iagreenfield-nitrogen/ (c) A 100 short-ton-per-day plant was completed in Nebraska in 2018 at a cost of $\$ 75 \mathrm{M}$ or $\$ 826,000$ per MT-NH $3 /$ day capacity. Brown, T. Ammonia Industry "Geneva, NE - Fortigen"

https://ammoniaindustry.com/geneva-ne-fortigen/

(70) U.S. Energy Information Administration, Henry Hub Natural Gas Spot Price

https://www.eia.gov/dnav/ng/hist/rngwhhdm.htm

(71) Project documentations available at $\mathrm{http}: / / \mathrm{www} \cdot \mathrm{hydrogen} \cdot$ energy.gov/h2a production.html

(72) A 750,000 MT- $\mathrm{NH}_{3} /$ year (2055 MT- $\mathrm{NH}_{3} /$ day) plant (Yara/BASF) built in Freeport, TX, at a cost of $\$ 600 \mathrm{M}$, is reported to employ 35 permanent workers. Brown, T. Ammonia Industry "Freeport, TX - Yara/BASF" 31 July, 2018: https://ammoniaindustry.com/freeport-tx-yara-basf/

(73) Saur, G.; Ramsden, T.; James, B.; Colella, W. Future Distributed Hydrogen Production from Grid PEM Electrolysis NREL, 2018 https://www.nrel.gov/hydrogen/h2a-production-case-studies.html

(74) Makhlouf, A.; Serradj, T.; Cheniti, H., Life cycle impact assessment of ammonia production in Algeria: A comparison with previous studies Environmental Impact Assessment Review 2015, 50, 35-41.

(75) Kugler, K.; Ohs, B.; Scholz, M.; Wessling, M., Towards a carbon independent and $\mathrm{CO}_{2}$-free electrochemical membrane process for $\mathrm{NH}_{3}$ synthesis Phys. Chem. Chem. Phys. 2014, 16, 6129-6138.

(76) Lindley, B. M.; Appel, A. M.; Krogh-Jespersen, K.; Mayer, J. M.; Miller, A. J. M., Evaluating the Thermodynamics of Electrocatalytic $\mathrm{N}_{2}$ Reduction in Acetonitrile ACS Energy Lett. 2016, 698-704.

(77) Xue, X.; Chen, R.; Yan, C.; Zhao, P.; Hu, Y.; Zhang, W.; Yang, S.; Jin, Z., Review on photocatalytic and electrocatalytic artificial nitrogen fixation for ammonia synthesis at mild conditions: Advances, challenges and perspectives Nano Research 2019, 12, 1229-1249.

(78) ERCOT Market Prices, Historical Real-Time Market Load Zone and Hub Prices

http://www.ercot.com/mktinfo/prices . For more detailed information about ERCOT see http://www.ercot.com/about

(79) U.S. Energy Information Administration, "Electricity. Average Price by State by Provider" (1990-2017)

https://www.eia.gov/electricity/data/state/ Electricity Price and Expenditure Estimates, 2017

https://www.eia.gov/state/seds/data.php?incfile=/state/seds/sep_fuel/html/fuel_pr_es.html\&sid=US (downloaded June 30, 2019)

(80) Farm Futures https://www.farmprogress.com/story-weekly-fertilizer-review-0-30765

(81) Coefficients in eq 14: $39.7 \mathrm{MWh}$ is the theoretical energy required to produce $1 \mathrm{mt}-\mathrm{H}_{2} ; 5.632$ is the ratio of mass of $\mathrm{NH}_{3}$ produced per unit mass of $\mathrm{H}_{2}$ assuming $100 \%$ efficiency of the $\mathrm{H}-\mathrm{B}$ synthesis; $1.33 \mathrm{MWh}$ is the energy required to run the $\mathrm{H}-\mathrm{B}$ plant per $\mathrm{mt}-\mathrm{NH}_{3}$ produced.

(82) This consideration also implies (although not added to the total costs shown in Table 8) the need for additional $\mathrm{H}_{2}$ storage capacity for times when $\mathrm{H}_{2}$ is not being produced by the electrolyzer.

(83) St. John, Jeff "Texas Grid Operator Reports Fuel Mix Is Now 30\% Carbon-Free", Greentechmedia, January 23, 2019, https://www.greentechmedia.com/articles/read/a-snapshot-of-texas-growing-appetite-for-wind-and-solar-power - gs.1krpiy

(84) Popovich, N., How Does Your State Make Electricity? New York Times December 24, 2018.

(85) Pfromm, P. H., Towards sustainable agriculture: Fossil-free ammonia J. Renew. Sustain. Energy 2017, 9, 034702. 
(86) Pindyck, R. S., The social cost of carbon revisited J. Environ. Econ. Manage. 2019, 94, 140-160.

(87) Ricke, K.; Drouet, L.; Caldeira, K.; Tavoni, M., Country-level social cost of carbon Nature Clim. Change 2018, 8, 895-900.

(88) IPCC, 2014: Climate Change 2014: Synthesis Report. Contribution of Working Groups I, II and III to the Fifth Assessment Report of the Intergovernmental Panel on Climate Change [Core Writing Team, R.K. Pachauri and L.A. Meyer (eds.)]. IPCC, Geneva, Switzerland, p 87.

(89) McKinley, J.; Plumer, B., New York to Approve One of the World's Most Ambitious Climate Plans. New York Times June 18, 2019, 2019.

(90) Annual Energy Outlook 2019 With Projections to 2050, U. S. Energy Information Administration, https://www.eia.gov/outlooks/aeo/pdf/aeo2019.pdf

(91) Creutzig, F.; Agoston, P.; Goldschmidt, J. C.; Luderer, G.; Nemet, G.; Pietzcker, R. C., The underestimated potential of solar energy to mitigate climate change Nat. Energy 2017, 2, 17140.

(92) Gilbert, A. Q.; Sovacool, B. K., Looking the wrong way: Bias, renewable electricity, and energy modelling in the United States Energy 2016, 94, 533-541.

(93) Levelized Cost and Levelized Avoided Cost of New Generation Resources in the Annual Energy Outlook 2019,

U. S. Energy Information Administration, February 2019

https://www.eia.gov/outlooks/aeo/pdf/electricity generation.pdf

(94) Service, R. F., Solar plus batteries is now cheaper than fossil power Science 2019, 365, 108.

(95) Audoly, R.; Vogt-Schilb, A.; Guivarch, C.; Pfeiffer, A., Pathways toward zero-carbon electricity required for climate stabilization Applied Energy 2018, 225, 884-901.

(96) Sachs, J. D.; Schmidt-Traub, G.; Williams, J., Pathways to zero emissions Nat. Geosci. 2016, 9, 799.

(97) Meckling, J.; Sterner, T.; Wagner, G., Policy sequencing toward decarbonization Nat. Energy 2017, $2,918-922$.

(98) Sivaram, V.; Kann, S., Solar power needs a more ambitious cost target Nat. Energy 2016, 1, 16036.

(99) Levelized Cost and Levelized Avoided Cost of New Generation Resources in the Annual Energy Outlook 2019,

U.S. Energy Information Administration, Appendix B, Table B3

https://www.eia.gov/outlooks/aeo/pdf/electricity_generation.pdf

(100) Grigas, A., The New Geopolitics of Natural Gas. Harvard University Press: Cambridge, MA, 2017.

\section{Acknowledgements}

We thank the NSF Chemical Catalysis Program of the Chemistry Division for funding this collaborative project through Grants CHE-1665146 (GH and ASG), CHE-1665137 (JMM and PLH), and CHE-1665135 (AJMM).

\section{Competing interests}

The authors declare no competing interests. 


\section{Appendix}

Table S1. Total cost (USD, energy plus fixed costs) per $\mathrm{mt}$ ammonia produced as a function of energy efficiency, energy costs, capital and operating expenses, with varying energy pricing cut-offs for operation using 2017 ERCOT real-time market prices (ERCOT Houston Loading Zone).

\begin{tabular}{|c|c|c|c|c|c|c|c|c|c|c|c|c|}
\hline \multicolumn{2}{|c|}{ LZ_HOUSTON_LZEW } & & 1 & 2 & 3 & 4 & 5 & 6 & 7 & 8 & 9 & 10 \\
\hline & & $\Delta(\$ / M W h)^{a}$ & 20 & 30 & 25 & 10 & 20 & 30 & 25 & 25 & 25 & 25 \\
\hline 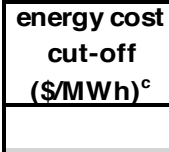 & $\begin{array}{c}\% \text { time } \\
\text { operating }^{d}\end{array}$ & $\begin{array}{c}\text { average } \\
\text { energy cost } \\
(\$ / M W h)^{\mathrm{e}}\end{array}$ & & & \multicolumn{5}{|c|}{ Total cost (electricity plus fixed) (\$/MT-NH3) } & & & \\
\hline 53.6 & 97 & 22.59 & 307 & 360 & 468 & 359 & 446 & 532 & 735 & 953 & 567 & 450 \\
\hline 39.0 & 94 & 21.88 & 305 & 359 & 465 & 356 & 442 & 529 & 727 & 943 & 566 & 445 \\
\hline 33.1 & 90 & 21.28 & 306 & 359 & 464 & 354 & 441 & 527 & 723 & 936 & 568 & 442 \\
\hline 30.5 & 85 & 20.67 & 307 & 361 & 464 & 354 & 440 & 527 & 719 & 929 & 573 & 439 \\
\hline 28.6 & 80 & 20.11 & 310 & 364 & 465 & 355 & 441 & 527 & 717 & 924 & 579 & 437 \\
\hline 2.6 & 1 & -0.36 & 7675 & 7729 & 7772 & 7653 & 7740 & 7826 & 7910 & 8023 & 15353 & 3998 \\
\hline \multicolumn{3}{|c|}{ per ton cost energy only $(24 / 7)^{f}$} & 156 & 156 & 280 & 295 & 295 & 295 & 402 & 535 & 295 & 295 \\
\hline \multicolumn{3}{|c|}{ per ton cost energy $+\Delta(24 / 7)^{g}$} & 264 & 317 & 521 & 396 & 497 & 598 & 746 & 995 & 548 & 548 \\
\hline & \multicolumn{2}{|c|}{ per ton fixed costs $(24 / 7)^{\mathrm{h}}$} & 73.5 & 73.5 & 73.5 & 73.5 & 73.5 & 73.5 & 73.5 & 73.5 & 147.0 & 36.75 \\
\hline & \multicolumn{2}{|c|}{ per ton total costs $(24 / 7)$} & 337 & 391 & 594 & 469 & 571 & 672 & 820 & 1068 & 695 & 585 \\
\hline
\end{tabular}

a) $\Delta$ : difference between wholesale electricity price and price paid

b) Fixed costs (capital and operating expenses) per mt assuming full-time operation at capacity

c) Greatest wholesale electricity price at percent operating time indicated (i.e. pricing at percentile indicated)

d) Percent time operating, assuming full operation at indicated pricing level or lower

e) Average cost of energy during time operating

f) Energy cost (not including $\Delta$ ) per mt assuming full-time operation at capacity

g) Energy cost (including $\Delta$ ) per mt assuming full-time operation at capacity 